\title{
The Nereid on the rise: Platynereis as a model system
}

\author{
B. Duygu Özpolat ${ }^{*} \mathbb{0}$, Nadine Randel ${ }^{2^{*}} \mathbb{C}$, Elizabeth A. Williams ${ }^{3^{*}} \mathbb{C}$, Luis Alberto Bezares-Calderón ${ }^{4^{*}}$, \\ Gabriele Andreatta ${ }^{5} \mathbb{D}$, Guillaume Balavoine ${ }^{6} \mathbb{D}$, Paola Y. Bertucci ${ }^{7}$, David E. K. Ferrier ${ }^{8} \mathbb{D}$, Maria Cristina Gambi $^{9} \mathbb{D}_{\text {, }}$

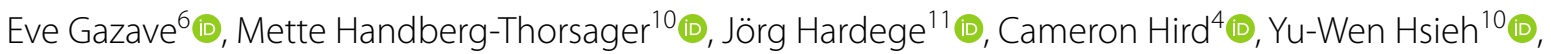

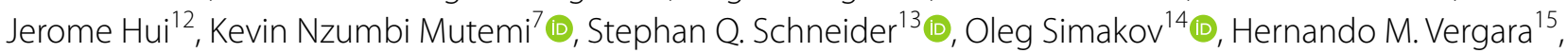

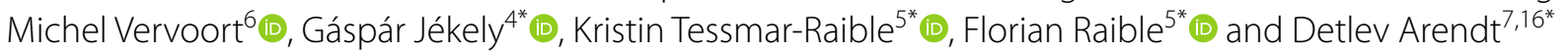

\begin{abstract}
The Nereid Platynereis dumerilii (Audouin and Milne Edwards (Annales des Sciences Naturelles 1:195-269, 1833) is a marine annelid that belongs to the Nereididae, a family of errant polychaete worms. The Nereid shows a pelagobenthic life cycle: as a general characteristic for the superphylum of Lophotrochozoa/Spiralia, it has spirally cleaving embryos developing into swimming trochophore larvae. The larvae then metamorphose into benthic worms living in self-spun tubes on macroalgae. Platynereis is used as a model for genetics, regeneration, reproduction biology, development, evolution, chronobiology, neurobiology, ecology, ecotoxicology, and most recently also for connectomics and single-cell genomics. Research on the Nereid started with studies on eye development and spiralian embryogenesis in the nineteenth and early twentieth centuries. Transitioning into the molecular era, Platynereis research focused on posterior growth and regeneration, neuroendocrinology, circadian and lunar cycles, fertilization, and oocyte maturation. Other work covered segmentation, photoreceptors and other sensory cells, nephridia, and population dynamics. Most recently, the unique advantages of the Nereid young worm for whole-body volume electron microscopy and single-cell sequencing became apparent, enabling the tracing of all neurons in its rope-ladder-like central nervous system, and the construction of multimodal cellular atlases. Here, we provide an overview of current topics and methodologies for P. dumerilii, with the aim of stimulating further interest into our unique model and expanding the active and vibrant Platynereis community.
\end{abstract}

Keywords: Annelida, Spiralia, Marine model species, Evo-devo, Integrative biology

\footnotetext{
*Correspondence: dozpolat@mbl.edu; nr479@cam.ac.uk; e.williams2@exeter ac.uk; L.A.Bezares-Calderon@exeter.ac.uk; g.jekely@exeter.ac.uk; kristin. tessmar@mfpl.ac.at; florian.raible@univie.ac.at; arendt@embl.de

${ }^{1}$ Eugene Bell Center for Regenerative Biology and Tissue Engineering, Marine Biological Laboratory, Woods Hole, MA 02543, USA

2 Department of Zoology, University of Cambridge, Downing Street, Cambridge CB2 3EJ, UK

${ }^{3}$ Biosciences, College of Life and Environmental Sciences, University of Exeter, Exeter, UK

${ }^{4}$ Living Systems Institute, University of Exeter, Stocker Road, Exeter, UK

${ }^{5}$ Max Perutz Labs, University of Vienna, Dr. Bohr-Gasse 9/4, 1030 Vienna, Austria

${ }^{7}$ European Molecular Biology Laboratory, Developmental Biology Unit, Meyerhofstrasse 1, 69117 Heidelberg, Germany

Full list of author information is available at the end of the article
}

\begin{abstract}
Natural habitat and life cycle Habitat

The Platynereis genus shows almost cosmopolitan distribution and has been found in the Mediterranean, the North Sea, North Atlantic from North America to Brazil, Persian Gulf, Red Sea, Indian Ocean, Pacific, and along the coasts of Southwest Africa [1]. P. dumerilii as a species complex $[2,3]$ is widely distributed throughout the European Seas from Scandinavia and Great Britain to the French Atlantic coast, Iberian Peninsula and Canary Islands, all along the Mediterranean coasts and the Black Sea $[4,5]$.
\end{abstract}

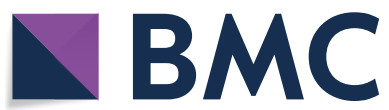

(c) The Author(s) 2021. Open Access This article is licensed under a Creative Commons Attribution 4.0 International License, which permits use, sharing, adaptation, distribution and reproduction in any medium or format, as long as you give appropriate credit to the original author(s) and the source, provide a link to the Creative Commons licence, and indicate if changes were made. The images or other third party material in this article are included in the article's Creative Commons licence, unless indicated otherwise in a credit line to the material. If material is not included in the article's Creative Commons licence and your intended use is not permitted by statutory regulation or exceeds the permitted use, you will need to obtain permission directly from the copyright holder. To view a copy of this licence, visit http://creativecommons.org/licenses/by/4.0/. The Creative Commons Public Domain Dedication waiver (http://creativeco mmons.org/publicdomain/zero/1.0/) applies to the data made available in this article, unless otherwise stated in a credit line to the data. 
Platynereis dumerilii occurs preferentially in shallow vegetated habitat, both on hard bottoms covered with macroalgae [6-9], as well as associated with seagrass beds $[10,11]$. During the pre-mature adult stage, $P$. dumerilii dwells in mucous tubes that it secretes and constructs by incorporating small pieces of algae from the surrounding environment [12]. This behavior is called "gardening", since the algal species are often used as food by the worms. It is also thought to reduce the risk of predation [13]. Tubes are most commonly found attached to various macrophytes growing on shallow hard bottoms, including seagrass, brown, green and red algae $[7,8,14-17]$.

Most recorded collections of $P$. dumerilii occur at depths down to $10 \mathrm{~m}$, with sea surface salinity of 30-35 practical salinity units (PSU; equivalent to o/00) and at temperatures between 10 and $15{ }^{\circ} \mathrm{C}$ [1]. However, the species is also reported at greater depths, associated with rocky banks and gorgonians, although these records [6] seem associated with macroalgae drifting from shallower habitat and under decay. However, the question of the depth distribution of $P$. dumerilii is still open and requires further investigation, for example whether speciation is involved. P. dumerilii is also reported for tidal flats covered by brown Laminaria beds [17], in algal decaying debris [18], and associated with the flowering spathes of Zostera marina [19]. Lab-based experiments suggest that the juveniles and pre-mature adults are most active at night, when they emerge from their tubes to hunt for food [20]. P. dumerilii juveniles and pre-mature adults feed primarily on benthic diatoms, foraminifera, coccolithophores, and macroalgae fragments collected close to their tube entrance, or from the epiphytic community of their macrophyte hosts $[13,14]$.

\section{Life cycle}

The lifecycle of $P$. dumerilii features several significant transitions (Fig. 1c). The morphology of developmental and life cycle stages, as well as the sequence of developmental transitions and metamorphoses have been described in great detail [14, 21-23]. Eggs and sperm are shed into the water, where fertilization and embryonic development occur. Embryos secrete a protective jelly coating, which gives them added buoyancy and prevents polyspermy [21]. After $24 \mathrm{~h}$ at $18{ }^{\circ} \mathrm{C}$, free-swimming trochophore larvae hatch and spend about 2 days as plankton. These larvae do not feed, and live on maternally provided yolk platelets and lipid droplets. After 3 days in the plankton, the late trochophores start searching the sea floor in preparation for their settlement. They then undergo a habitat transition during which they settle to the benthic zone, and start feeding after 6 days only. These small, three-segmented juvenile errant worms (also called young worms, or nectochaetes) have a head, a pygidium, and three cheatigerous segments bearing parapodia and chaetae (bristles). After around 2 weeks post-fertilization they begin to grow by adding new segments to their posterior end from the posterior growth zone in front of the pygidium. The juveniles then choose a spot to secrete their mucous tube, usually the stem or leaves of macrophytes or macroalgae.

Upon addition of their 6th segment, juveniles undergo a cephalic metamorphosis in which the first cheatigerous segment fuses with the head and transforms into posterior tentacular cirri [22-24]. Juveniles feed and grow for at least 2 months. Gonial clusters start to populate most of the trunk segments when worms reach 35-40 segments in length [25]. Growth and maturation of gametes starts in the coelom when the worms are approximately 50 segments in size, and undergo maturation in worms $\sim 70$ segments in size [14, 23, 26-28]. During sexual metamorphosis, the gut degenerates, the eyes increase in size, and the parapodia and musculature profoundly change into the swimming form [22, 29]. Spawning of $P$. dumerilii peaks around 1 week after the full moon phase [20]. Aspects of sexual metamorphosis in this heteronereid phase are regulated internally by levels of the sesquiterpenoid hormone, methylfarnesoate [30]. In the Mediterranean Sea, Scotland, and the Black Sea, $P$. dumerilii is reported to reproduce from late spring to late fall $[18,31,32]$. After metamorphosis, the sexually mature male and female $P$. dumerilii leave their tubes and swim to the sea surface, where they perform a nuptial dance, which culminates in gamete release and external fertilization. Following spawning, the adults die.

\section{Lab culture and field collection \\ Laboratory culture}

Platynereis dumerilii has been cultivated throughout its life cycle and studied in the laboratory for more than 70 years. Thus, one of the key advantages of this model system is controlled breeding, which enables the establishment and maintenance of inbred, transgenic and mutant strains (Additional file 2: Table S2). Carl Hauenschild established culture conditions and provided a first description of the life cycle [23]. He also established the distinction between the two naturally co-occurring sibling species $P$. dumerilii and $P$. massiliensis [36, 37]. Using P. dumerilii, Carl Hauenschild was the first to show that moon-controlled monthly cycles still persist in the laboratory, and that natural moonlight can be mimicked (at least to some extent) by a light bulb $[38,39]$. Current laboratory cultures of $P$. dumerilii, which range in scale from a few hundred to tens of thousands of worms per culture, all trace back to the initial culture established by Carl Hauenschild in the 1950s, and originate from the Bay of Naples (Italy) with sporadic in-crossing from other 

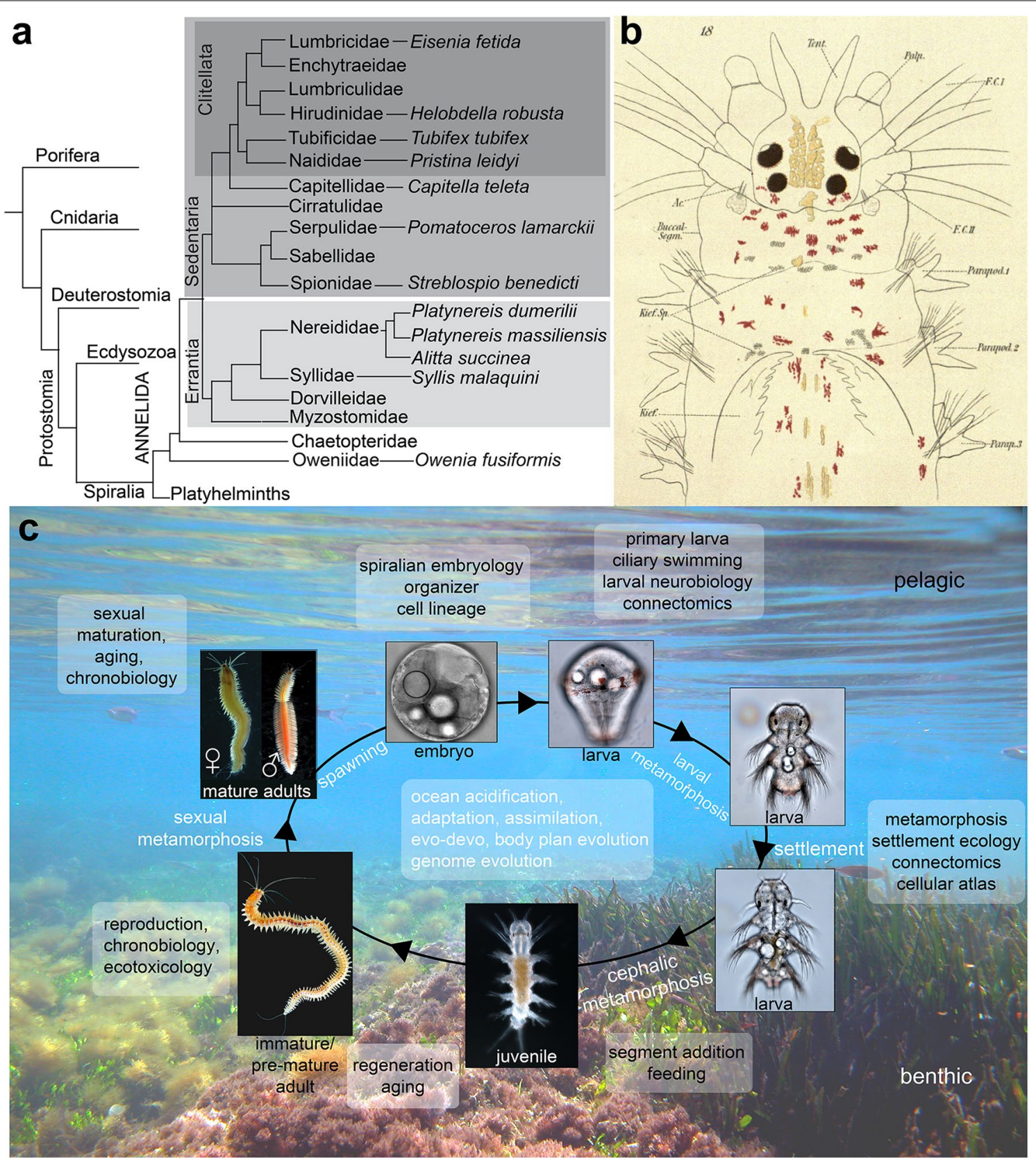

Fig. 1 a Phylogenetic position of P. dumerilii in Annelida and in Metazoa [33, 34]. b Platynereis head morphology (from [35]). Ac: acicula; Buccal Segm: buccal segment; F.C. (I, II): tentacular cirri; Kief:. jaw; Palp: palpae; Parapod: parapodia; Tent: antennae. c Life cycle of P. dumerilii. Embryonic, larval, juvenile, and adult stages are shown, along with research areas that focus on the different life cycle stages (boxes). Immature adults: no visible maturing gametes; pre-mature adults: maturing gametes in the coelom; mature adults: fully metamorphosed and ready to spawn

locations such as Arcachon [21, 22]. Laboratory culture techniques were more recently improved [40,41].

Egg-to-egg life cycle can be as short as 11 weeks depending on culturing conditions, but regularly takes 3 months or longer. Sexual maturation is easily synchronized by using artificial moon light, and mature worms can be obtained throughout the year by keeping the colony under "summer" day- and night-light conditions. Keeping the worms under different lunar light-cycle conditions also allows mature worms to be obtained throughout the month, therefore, with a large colony size, embryos are always available. As $P$. dumerilii reproduces only once before death, it is important to keep a minimum colony size in order to obtain maturing males 


\section{History of the term Nereididae}

In Greek mythology, Nereids were the 50 daughters of Nereus, the old man of the sea. They symbolized the beauty and kindness of the seas and were often referred to as goddesses of sea or sandy beaches. Some millennia later, another group of sisters would be named after Nereids: the family of Annelids known as the Nereididae. Among the ranks of Nereididae, Platynereis dumerilii (Audouin \& Milne Edwards) [209] is the type species of the genus Platynereis (Kinberg 1865) [210] (Fig. 1a). While Platynereis dumerilii and its sisters may not be widely appreciated for their beauty as the original Nereids (Fig. 1b), these impressive worms quickly become the beloved lab companions of those who study them. Unlike the daughters of Nereus who lived in the Aegean Sea, today's Nereids are all over the world, including many research labs on several continents.

and females at the same time to be able to propagate and maintain a particular strain. For wild-type strains, lab colony sizes can be as small as 500-1000 worms at a time (Hird et al., unpublished). Based on the number of mature animals needed, it is easy to scale up or down $P$. dumerilii cultures [41]. While practices vary across labs, the worms typically can be cultured in food-safe, nonreactive plastic containers with $500-1500 \mathrm{~mL}$ sea water.

Laboratory culture of earlier life stages of $P$. dumerilii (embryos and larvae) so far involved natural sea water transported from the sea. However, recent efforts to develop new culturing methods solely based on artificial seawater from commercially available sea salt mixes have proven successful (Hird et al., unpublished). In addition, progress has been made on standardizing and improving feeding, such as spirulina powder instead of spinach for juveniles [41] and using algae cocktails and live feeds for faster larval settlement and early development, respectively (Hird et al., unpublished). One of the critical future advances will be developing and improving cryopreservation methods for larvae or sperm for maintaining and sharing transgenic or mutant strains [42].

\section{Field collection}

Field collection of Platynereis species at juvenile stages is relatively easy since the worms are associated with shallow vegetated habitat, as well as in the intertidal zone such as seagrass meadows. While seagrass collection requires SCUBA diving, collection from very shallow hard bottoms and tidal flat habitats can be accomplished via snorkeling. Collection involves removal of algal thalli inside fabric bags and then sorting of the worms in the lab by shaking the thalli in seawater, or by inspection under a stereomicroscope. Generally, $P$. dumerilii has a large dispersal potential, having a pelagic larval stage, as they can survive weeks without food by relying on maternally provided resources [8].

Collecting fully mature adults can be carried out using a strong light at night as the fully mature worms leave their benthic habitat and move close to the ocean surface to swarm and reproduce. As the swarming time is highly synchronized by the lunar cycle, timing of mature worm collection can be planned accordingly. Sexually mature adult worms can be attracted to the light, detected based on their characteristic circular movements, and collected using a fine net $[40,43]$. While collecting $P$. dumerilii is a great field experience, most labs do not need to do any collecting, and researchers who are interested in culturing $P$. dumerilii can simply request larvae from established labs, which will happily share animals. This may indeed be the preferable option because these lab strains have been used to generate the genomic and transcriptomic resources, and therefore are better suited for molecular studies.

\section{Major interests and research questions}

Below we present major research interests following the life cycle stages, starting with embryogenesis:

\section{Platynereis embryology}

As a member of the spiralian clade, the Platynereis embryo shows highly stereotypical and synchronous development with a spiral cleavage pattern [44]. $P$. dumerilii embryos have unequal cleavage, and during the first two cell divisions, 4 distinct blastomeres called $\mathrm{A}, \mathrm{B}, \mathrm{C}$, and $\mathrm{D}$, are formed; the $\mathrm{D}$ blastomere (or the D-quadrant) is the largest of these (Fig. 2a). The spiral cleavage is then easily followed from 4to 64-cell stages and comprises a series of invariant asymmetric cell divisions (Fig. 2a). Therefore, embryonic cells can be individually identified by their position and size, and the cell lineages can be linked to particular cell fates similar to the nematode C. elegans and ascidian embryos [45-49]. Since the spiralian mode of embryogenesis is utilized by many phyla within Spiralia, it constitutes the starting point for many divergent adult body plans [44, 50-52]. Indeed, P. megalops embryos were among the first to be used for cell lineage and cell-fate mapping in the late nineteenth century, and these appear identical to $P$. dumerilii [53]. Several studies built upon these early works with microscopy, microinjection of embry- 


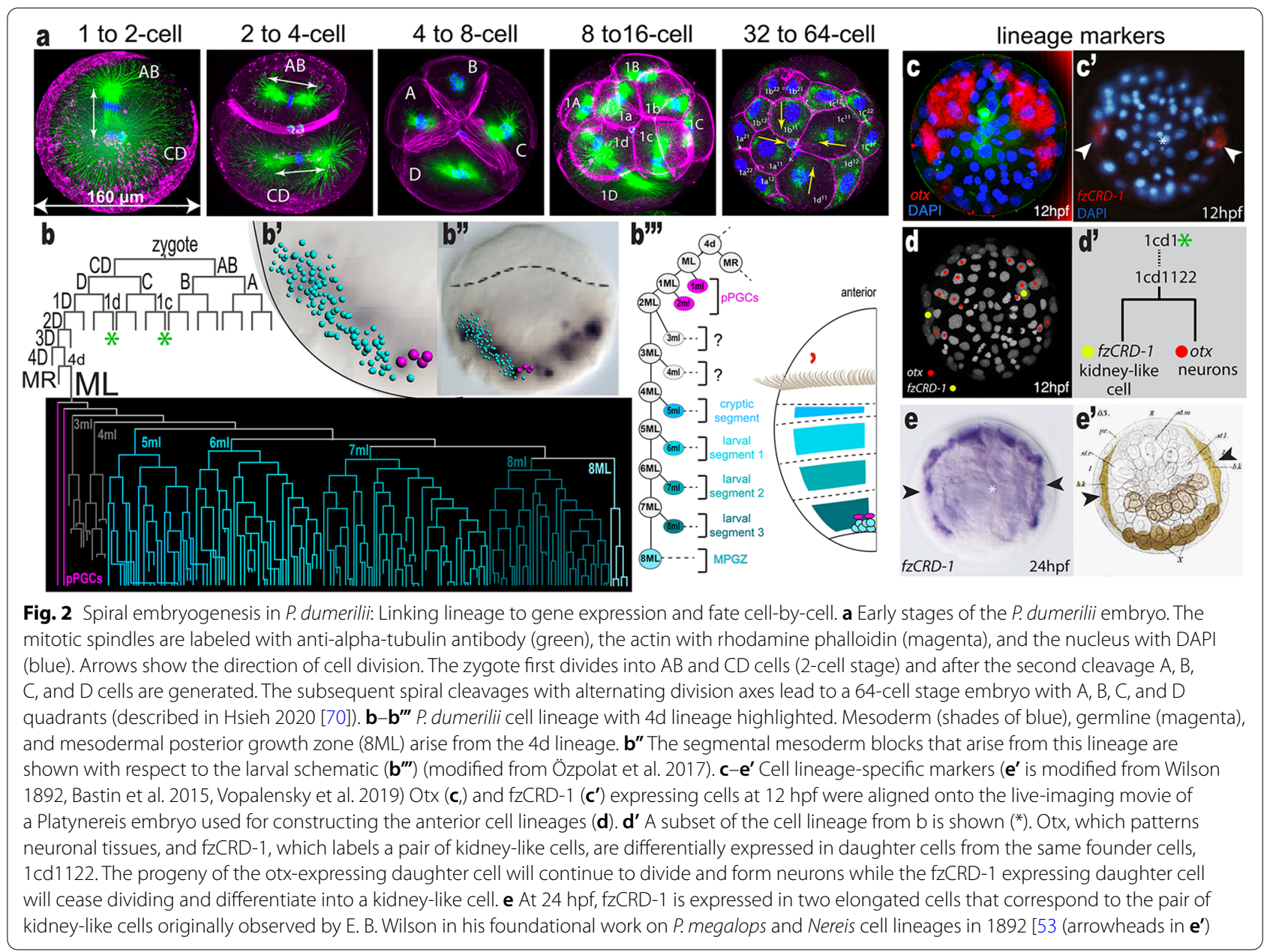

onic cells, and the use of fluorescent dyes for cell-fate mapping [54-57]. Fertilization, gametogenesis and oocyte maturation have also been extensively studied in $P$. dumerilii and P. megalops $[27,28,43,58,59]$.

Linking cell lineages and individual cells to gene expression and cell fate is possible in $P$. dumerilii [57, 60-63]. Embryos are large enough to microinject for fluorescent labeling of cell nuclei and membrane, they show fast recovery after injection, and are small and transparent enough to image for several days (Additional file 1: Table S1). In addition, various sequencing approaches for obtaining developmental stage-specific transcriptomes have been used [64-66]. These resources allow the identification of transcription factors and signaling pathways and assist in mapping gene expression to cell lineages and cell fates. Two recent studies identified the precise single-cell origins of segmental mesoderm, germline, and the mesodermal posterior growth zone, along with cell cycling dynamics [57, 60] (Fig. 2b). Another study focused on the cell lineages forming the head region and revealed the transition from spiral cleavage to bilaterally symmetric arrangement of founder cells in the head [63]. Here, one bilateral symmetrical founder cell divides to give rise to daughter cells with distinct fates: one otx-expressing daughter cell will eventually differentiate into neuronal tissue, and another daughter cell expressing $f z C R D-1$ (frizzled cysteine-rich domain 1) will terminally differentiate into a kidney-like cell [53, 63, 67] (Fig. 2c-e). Thus, lineage-tracing and gene expression studies are linked to individual differentiated cells and cell types. These studies also allow an evolutionary comparison of cell types across the phylogenetic tree [68].

One area of interest in spiralian embryos is a deeper understanding of the molecular basis of asymmetric cell divisions and the cytoskeletal dynamics of the spiral cleavage mode itself. Currently, little is known about the underlying molecules and biophysical mechanisms, but with the establishment of new 
imaging techniques in $P$. dumerilii, quantitative studies of the dynamics of the spiralian development are now possible $[69,70]$. In recent years, comparative work between spirally cleaving embryos has gained attention [44]. In several spiralians including annelids, the specialized cells of the D-quadrant (named $2 \mathrm{~d}$ and 4d) (Fig. 2) possess inductive capabilities that affect dorsal-ventral patterning of the embryos (the spiralian organizer). Experimental manipulations suggest the existence of so far unknown molecular determinants in the zygote that establish the D quadrant in $P$. dumerilii, including $2 \mathrm{~d}$ and $4 \mathrm{~d}$. The discovery of these determinants is now within reach $[71,72]$. Altogether, these data shed light onto which signaling molecules and pathways are operating during spiralian development, and when and where tissue specification and differentiation take place [63, 64, 67, 73-75] (Fig. 2b”).

Spiralian embryos and larvae constitute a mosaic of stem cells and differentiating cells that continue to divide or stop dividing to form distinct cell types. The stereotypic cell lineages enable systems-level analyses as well as the molecular dissection of the intricate interplay of cell-cycle regulation, cell division, cell death, cell delamination, cell migration, cell-fate specification, and cell-type differentiation. This paves the way to unravel the cell and developmental biology of spiralian embryogenesis in unprecedented detail in future studies.

2. Sensory biology of the swimming trochophore larva

Platynereis dumerilii exhibits a pelago-benthic life cycle with non-feeding planktonic larvae called trochophore, followed by a bottom-dwelling stage after larval settlement and metamorphosis (Fig. 1c). The trochophore has many features in common with other ciliated larvae: an apical tuft, ciliary band cells, and a range of ciliated sensory cells. The shared gene repertoire, and morphological and developmental features of the $P$. dumerilii larva have prompted farreaching homology hypotheses on the evolution of structures such as the larval apical organ (a sensory structure common among primary larvae [76-78]) and the larval foregut [79]. More recent single-cell RNA-sequencing data from $P$. dumerilii larvae [62, 82] will enable further comparisons and bring a clearer picture of the cell-type complement of primary larvae, a stage assumed to have existed already early in metazoan evolution [80].

The relatively small size, simple nervous system and the ciliated planktonic stage shared with many other organisms-but lacking in the main model animals-are features that make the $P$. dumerilii larva a favorable system for investigating the sensory biology of zooplankton and the neuronal control of cilia. The larva has bands of locomotor cilia in the head, trunk and tail that beat in a tightly regulated pattern (Fig. 3a, b). The activity of the ciliary bands is, in turn, a function of the stimuli perceived and the larva's internal physiological state. Work in P. dumerilii is revealing the sensory cues, molecules and neuronal networks involved in the control of ciliary beating. The sensory cues known to alter ciliary beating include light and water-borne vibrations. For instance, the 1-day-old trochophore changes its swimming direction by differentially altering the beating on each side of the ciliary band [81]. In contrast, vibrations lead to sudden and transitory ciliary arrests of the entire band [82]. Ciliary band activity shows longer-term changes across the day that are induced by melatonin [83]. Other signaling molecules that affect ciliary band activity include neuropeptides, which alter ciliary beat frequency, ciliary arrests, or both, causing larvae to swim upwards or downwards [84]. The cells controlling ciliary band activity have been identified using a combination of serial electron microscopy and calcium imaging [83, 85]. Cholinergic, serotonergic and monoaminergic neurons form a neuronal network converging on the ciliary band cells that ultimately define their beating pattern [85]. How these cells control this pattern and how other molecules such as neuropeptides modulate this network, and therefore the swimming behavior of the larva, are exciting questions still waiting to be answered.

The seemingly small and simple $P$. dumerilii trochophore larva is equipped with a remarkable array of different sensory cell types. Most prominent among these are the two pairs of eyes on the dorsal side (adult eyes) and a pair of eyes on the ventral side (larval eyes) (Fig. 3c). The photoreceptor cells in these eyes are rhabdomeric and express multiple r-opsins and a Go-opsin [86-91]. In the center of the brain, two pairs of ciliary photoreceptor cells are recognizable due to their multiple ramified cilia (Fig. 3d). These cells express a ciliary opsin (c-Opsin1) [92]. Other sensory cell types can also be identified by their consistent spatial location and distinctive sensory cilia morphology. In P. dumerilii, sensory-neurosecretory cells are abundant in the apical organ [76-78]. The expression of neuropeptides in these sensory-neurosecretory cells allows immunostaining with antibodies to highlight their morphology, including axonal 


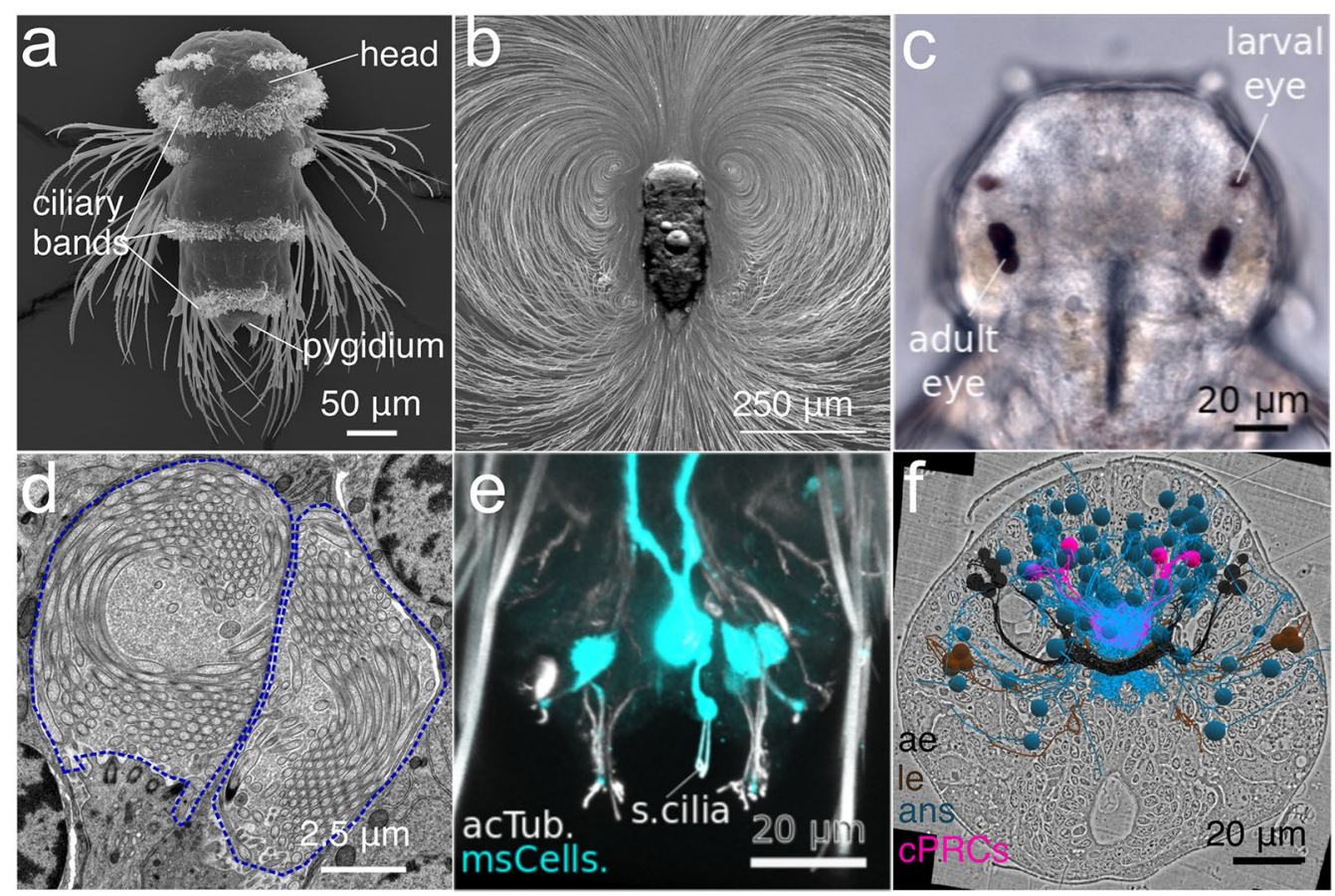

Fig. 3 Locomotor and sensory cilia in the P. dumerilii larva. a SEM micrograph of a larva at 3 days post-fertilization (dpf) (nectochaete stage). Ciliary bands in the head, trunk and tail (pygidium) propel the larva in the water. Dorsal view. b A 3 dpf larva engages in swimming, as visualized by the movement of microbeads added to the water. c Bright-field image of a $3 \mathrm{dpf}$ larva showing the location of adult and larval eyes. Dorsal view. $\mathbf{d}$ Transmission electron microscopy image of ciliary photoreceptor cells located in the larval brain. The sensory cilia (outlined in blue) of one of the two pairs of cells is shown. e Mechanosensory ciliated cells (msCells) in the pygidium labeled using a promoter construct. Acetylated tubulin labels sensory cilia (s.cilia). $\mathbf{f}$ EM volume reconstruction of the neurosecretory cells in the apical organ region of a 3 dpf larva. Ae: adult eye; le: larval eye; ans: apical nervous system; CPRCs: ciliary photoreceptor cells. Image in a by J. Berger; image in $\mathbf{d}$ by R. Shahidi

projection patterns [84, 93]. Transient and stable transgenesis have also allowed the identification of individual sensory cells [82, 89] (Fig. 3e). Some sensory cells can also be identified in $P$. dumerilii larvae during live imaging with the assistance of vital dyes, such as Mitotracker, which was used to identify chemosensory cells in the larval head [94].

Although most of the sensory cells in the larva await functional characterization, work on $P$. dumerilii has already shown how a combination of behavior, genetics and ecology can be harnessed to study sensory system function. The best-studied sensory modality in $P$. dumerilii larvae is light detection. Cell ablation, electron microscopy reconstruction and behavioral tracking in $P$. dumerilii have been used to understand different phototactic mechanisms in zooplankton. In the early larva, direct innervation of the ciliary band cells by the larval eyespot and spiral swimming account for light-directed swimming [81]. Older larvae use a more complex visual circuit that allows the detection of very small changes in light intensity through a feedback circuit motif [81, 95]. Targeted genome editing of Go-Opsin and c-Opsin1 was used to identify their role in detecting specific wavelengths/colors of light thereby regulating swimming depth $[88,90]$. A combination of microfluidics and calcium imaging enabled the identification of chemosensory centers in $P$. dumerilii larvae, such as the palps, antennae, and nuchal organ [96]. These studies provide the basis for future investigations on how the sensory systems allow the $P$. dumerilii larva to detect and respond to other cues such as temperature, pressure, and $\mathrm{pH}$, and how the larva integrates different cues to guide behavior in their natural habitat.

The larval stage of $P$. dumerilii ends with settlement onto the sea floor. This habitat transition requires the larva to use its sensory capacities to navigate the benthic habitat, find a beneficial site to settle and begin feeding and tube-building. Previous studies discovered that the neuropeptide myoinhibitory peptide (MIP) plays a role in the regulation of larval settlement and the initiation of feeding [94, 97]. Some MIP-expressing neurons with chemosensory morphology are found in the apical organ, an area implicated in the detection of environmental cues for larval settlement in aquatic larvae [77, 98] (Fig. 3f). 
Cells of the apical organ region have cilia with diverse morphologies, suggestive of several different sensory modalities [79] (Fig. 3f). Further studies are required to understand the specific function of the cells that populate the $P$. dumerilii larval apical organ and the different neuropeptidergic signaling pathways that may synergize with MIP to guide larval settlement.

3. The Nereid young worm as a model for cellular-resolution multimodal atlases and connectomics

The three-segmented young worm represents another key stage of the Nereid life cycle that has attracted strong interest by evolutionary developmental biologists, comparative anatomists and neurobiologists. As early as $3 \mathrm{dpf}$, the larva shows a prototype annelid body plan with many presumed ancestral features that have homologs across annelids, spiralians, protostomes, or even bilaterians. This includes individual cell types such as photoreceptors [92] and muscle cells $[99,100]$ to whole organs such as the axochord [99, 100] and brain regions such as the mushroom bodies [101]. Equipped with a complex rope-ladder-like nervous system, the three-segmented young worm moves around, changes substrate and explores the environment. At 5-6 dpf, when the young worm finally settles, the nervous system is almost fully differentiated-with all major parts of the ventral nerve cord, peripheral nervous system and brain in place, including rudimentary mushroom body stalks and calyces $[101,102]$. Still, at $6 \mathrm{dpf}$, the entire body contains no more than 12,000 cells comprising hundreds of cell types [103], which is a huge advantage relative to other model systems with cell counts in the millions for similar differentiated stages. For instance, the low number of cells per cell type allows simultaneous and complete capture of all body cell types in single-cell sequencing experiments; and the few neurons representing each neuron type permit tracing their connections for the entire nervous system $[61,85,104]$.

The high degree of developmental stereotypy that is characteristic for the embryonic spiral cleavage stages, manifests not only in the trochophore larva, but also in the nervous and muscular systems of the three-segmented young worm. This goes in concert with highly complex cellular arrangements and morphologies and the relatively low number of cells that force the bulk of cells into stereotypical and reproducible locations. The unique combination of mass reproduction, synchronicity and stereotypy allows obtaining thousands of individuals from the same batch at the same developmental stage (that only depends on time and temperature) and which are very similar in cell number, morphology and arrangement. This striking overall reproducibility of development and differentiation makes $P$. dumerilii ideal for creating multimodal cellular-resolution atlases for the entire body (Fig. 4). Beyond $6 \mathrm{dpf}$, young worms start feeding, which affects their developmental synchrony and, consequently, their stereotypy.

Leveraging these unique advantages, gene-expression atlases for multiple embryonic, larval, and young worm stages have been obtained through profiling by image registration (PrImR; [101]) and profiling by signal probability mapping (ProSPr; [105]) and currently comprise more than 250 differentially expressed genes [101, 105, 106] (Bertucci et al., in prep.) (Fig. 4). The systematic exploration of gene expression and co-expression patterns in a common reference framework facilitates an unbiased definition of molecular regions and cell types along the whole body $[101,105]$. This provides a new rigor in evo-devo studies, which traditionally relied on the comparison of broad spatial expression of only a few select genes [101] 105, 106]. Furthermore, the availability of gene expression atlases for multiple consecutive stages gives a dynamic picture of the lineage and molecular composition of cell types through development and differentiation (Bertucci et al., in prep). The power of multi-stage expression atlases allows, for example, to establish the developmental origin and differentiation path of neurons and glial cells (Bertucci et al., in prep.). This can be complemented and validated by lineage-tracing via targeted photoconversion of selected cells, and by the gene knockdown or knock-out of lineage-specific marker genes. Ultrastructure of these cells can be further resolved by registering a high resolution volume obtained by focussed ion beam milling combined with scanning electron microscopy (FIB-SEM) of a $6 \mathrm{dpf}$ young worm on the ProSPr atlas. Overall, diverse sensory morphologies including mechanosensory and chemosensory endings have been and are being molecularly and morphologically characterized (Bertucci et al., in prep.).

Following the same principle, the PrImR and ProSPr molecular atlases have been integrated at different levels with datasets of other modalities to obtain a more comprehensive picture of the Nereid cell types. Using the atlas gene set as a spatial reference system, it is possible to infer the anatomical origin of cells in single-cell RNA-Seq experiments [61, 104]. This allows the recovery of the original position of cells and complements the molecular information of the 


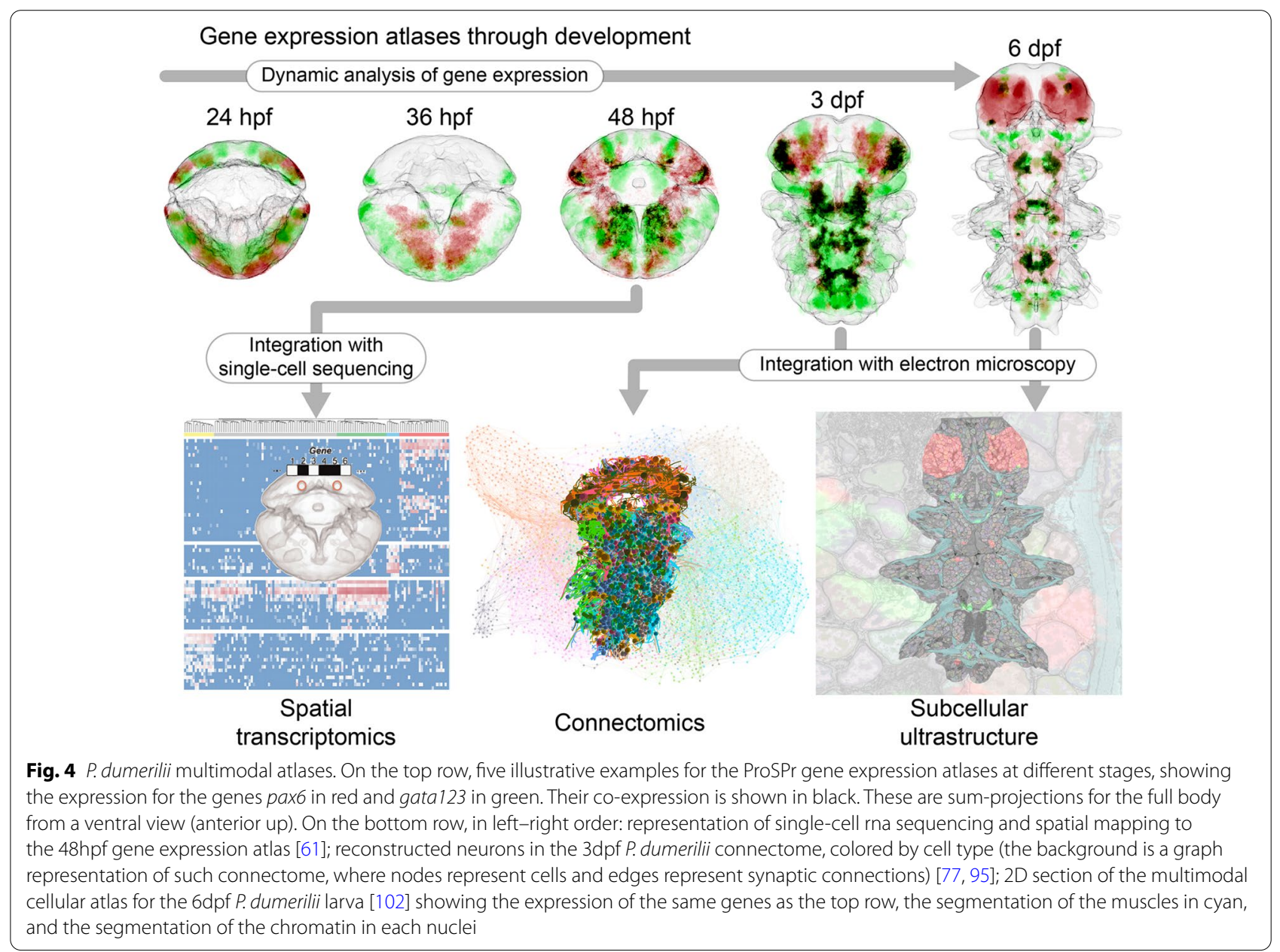

atlas in an unbiased manner (Fig. 4). This approach has revealed for example that the pre-metamorphic larva is composed of five distinct families of cell types that are likely conserved across animals [61, 104], and similar efforts are underway for the three-segmented young worm (Arendt laboratory, unpublished).

The small size of the three-segmented larval stages $(\sim 300 \mu \mathrm{m})$ also enables the acquisition and comprehensive analysis of nanometer-resolution whole-body serial electron microscopy datasets for the $3 \mathrm{dpf}[95$, 107] and the $6 \mathrm{dpf}$ young worm [102]. In the $3 \mathrm{dpf}$ worm, the complete morphological cell-type complement and neuronal connectome have been mapped, revealing 90 non-neuronal and 180 neuronal cell types [103] (Fig. 4). Transient transgenesis with cell type-specific regulatory sequences and immunogold EM have also been used to map neurotransmitter and neuropeptide content to the connectome resource $[85,108]$ providing a link to the gene expression atlas. For the $6 \mathrm{dpf}$ young worm, a full serial blockface electron microscopy (SBEM) volume has been registered to the ProSPr expression atlas, resulting in a full whole-body cellular-resolution alignment of gene expression with subcellular structures [102]. Together with the tracing of hundreds of randomly selected brain cells, this allows the exploration of cellular phenotypes and gene expression for the entire animal, and has enabled the unbiased characterization of morphologically defined tissues (Fig. 4).

The gene content of the $P$. dumerilii gene atlas so far reflects the focus of the community on specific organ systems (e.g., nervous system and musculature). Other systems are still underrepresented (e.g., nephridia, heart, midgut). In the near future, any bias will be removed by the mapping of single cell data to the atlas. Furthermore, expanded multimodal atlases will serve as a link between subcellular ultrastructure and connectomics, and various kinds of single-cell multi-omics data, generating ultrastructurally and molecularly complete whole-body reference frameworks that will enable a new dimension of cellularresolution linking of genotype and phenotype. 


\section{Platynereis as a model for chronobiology}

A further exciting feature of $P$. dumerilii is its chronobiology, as this worm integrates both solar and lunar cues into its life cycle. Like most animals, $P$. dumerilii possesses an inner oscillator with a period length of $\sim 24 \mathrm{~h}$, trainable by daylight. Behavioral and molecular data suggest that already the 2-day-old planktonic larvae undergo day-to-day changes [83]. Whether these changes are also maintained under constant conditions, and are therefore controlled by a circadian clock, remains to be tested. This represents a particularly interesting aspect, as it might help to further functionally dissect the role of daily timing mechanisms in diel-vertical migrations [81], a widespread and crucial phenomenon for marine ecosystems $[109,110]$.

During the worm's immature and pre-mature life, a circadian oscillator runs in both head and peripheral tissues of the trunk [20, 111]. The head circadian oscillator is essential for rhythmic locomotion and trunk gene expression. Meanwhile, the circadian expansion and contraction of the worm's peripheral pigmented cells (chromatophores) occur robustly for multiple days under constant darkness even after decapitation [111]. In mature animals, recent work has revealed a role of the $\sim 24$-h clock in setting the time of the nuptial dance. The clock displays a remarkable plasticity in response to naturalistic moon light: its periodicity changes when the moon phase changes from moonlit to darkness. This modulation of a "circadian-circalunidian" oscillator results in shifting the onset of the nuptial dance to the darkest hours of the night, a temporal niche changing over the course of the month (Fig. 5, middle panel). Functional interplay between the Cryptochrome L-Cry and the melanopsin ortholog r-Opsin 1 is required for this precise timing [112].

Furthermore, besides the "circadian-circalunidian" 24 h clock, $P$. dumerilii also possesses an inner "calendar" (monthly oscillator) whose main function is the synchronization of reproductive events to specific days of the month across the population. Mooncontrolled monthly or semi-monthly reproductive cycles are fundamental and widespread in the marine environment, yet, mechanistically they are poorly understood [113]. This monthly rhythm in $P$. dumerilii is under the control of an endogenous oscillator,

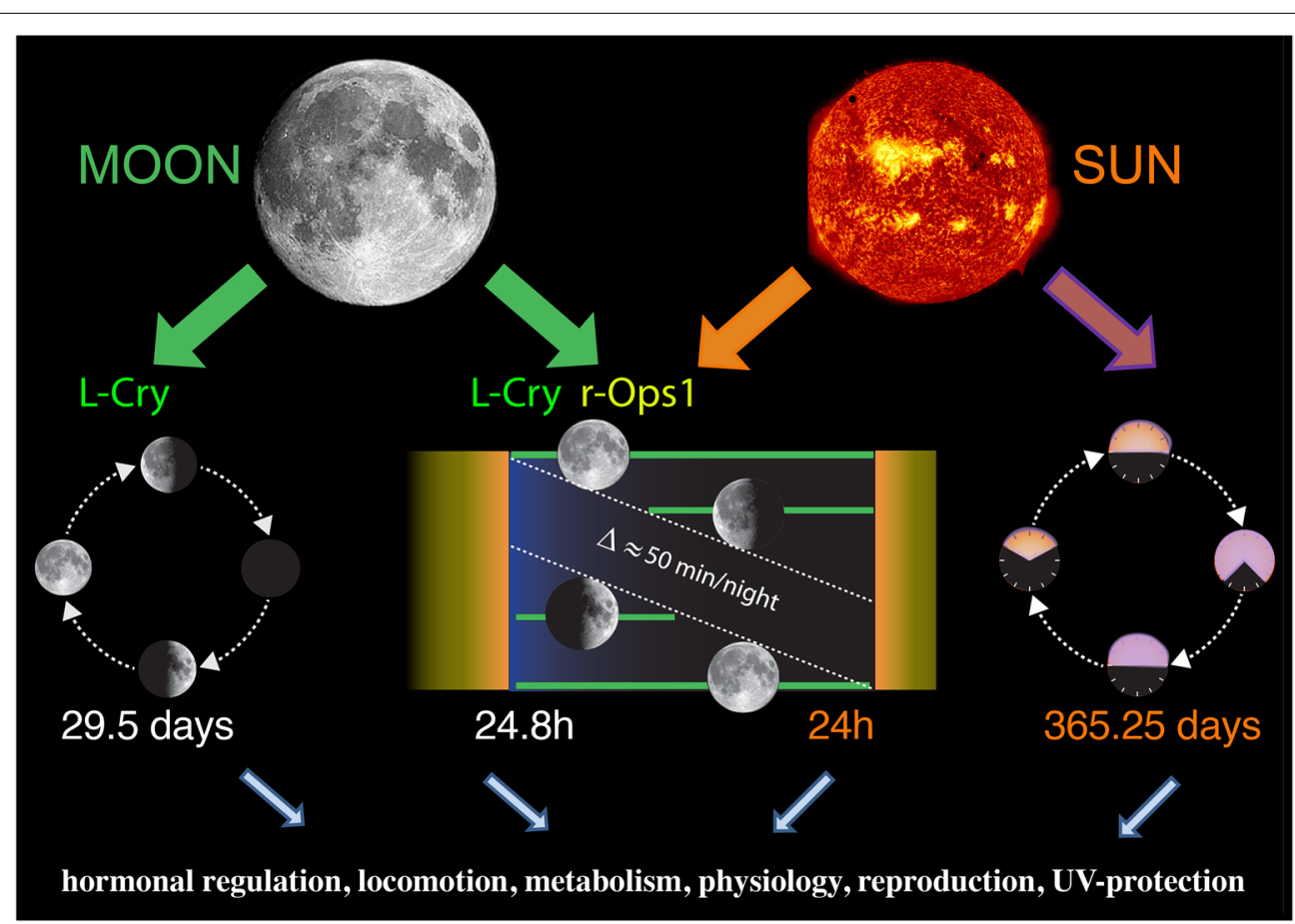

Fig. 5 Platynereis dumerilii chronobiology. Sun and moon provide different cues for the rhythms that govern the worms' biology. L-Cry functions as a valence detector, as well as a detector for the full moon phase. r-Ops1 biochemically cannot discriminate between sun or moonlight, but its high sensitivity allows it to precisely determine moonrise. While the 24-h-long clock relies on the "conventional" circadian transcription factor network, the nature of the circalunar (monthly) clock still remains unknown. It also remains to be tested if the annual changes are just direct responses to environmental changes or controlled by an endogenous annual oscillator 
the functions of which are maintained even in the absence of the oscillations of the conventional core circadian clock [20]. Systematic transcriptomic and proteomic data further support the notion that circadian and circalunar oscillators are distinct [114]. The Cryptochrome L-Cry is also required for the proper monthly oscillator function via its ability to discriminate between sun- and moonlight valence. Its specific activation kinetics by moonlight result in a fully activated state only when exposed to moon phases close to the full moon [115]. This provides a first mechanistic understanding of how animals can set an inner calendar specifically to the full moon phase [115].

As a laboratory species with significant functional tools and resources, $P$. dumerilii is one of the bestaccessible animal models to disentangle the cellular and molecular mechanisms of monthly oscillators. This is paralleled by efforts to obtain detailed knowledge on the light spectra and intensities in $P$. dumerilii's natural habitats. An almost year-long daylight dataset from $10 \mathrm{~m}$ depth and additional information from $4 \mathrm{~m}$ have been collected in a Mediterranean habitat [116]. These datasets revealed that short wavelengths, particularly in the UVA/deep violet light range, carry annual time information, as their intensity changes are shifted relative to the photoperiod. The photoreceptor c-Opsin1 helps convey this information in adult worms to adjust neuropeptide and neurotransmitter dynamics, as well as behavior (Fig. 5) [116, 117]. As UVA/deep violet light is typically not present in standard laboratory lighting, this research illustrates the opportunities from integrating environmental parameters into lab research. In turn, it suggests that there may be other behavioral or molecular paradigms that might be modulated under more natural conditions. It will be important in the future to test for these modulations. Furthermore, it is clear that additional light receptors are important to convey the (full)moon signals to the different oscillators of the animal. The nature of these receptors, as well as the molecular and cellular pathways downstream will certainly be important aspects of future research.

5. Stem cell-based posterior growth and regeneration in Platynereis

Once the three-segmented young worm stage ends, $P$. dumerilii juvenile worms grow during an extended phase of their life cycle, until sexual maturation occurs. Growth relies on the sequential addition of segments in an anterior-to-posterior temporal progression in the posterior body region, a process known as posterior growth (or posterior elongation). The general principle of posterior growth is shared by distantly related organisms including vertebrates, arthropods, annelids, and hemichordates, segmented or not, and pertains to the main clades of bilaterians [118-121]. P. dumerilii posterior growth has been studied in much detail and, it appears to rely on a ring-shaped growth zone in juveniles, anteriorly bordering the pygidium $[118,122]$. Labeling of S-phase cells by 5 -ethynyl-2'-deoxyuridine (EdU) pulse and chase experiments has shown the presence of proliferative cells in this growth zone, and cell divisions sustain tissue production and body elongation [62, 122]. Molecular characterization of the growth zone cells revealed the presence of ectodermal and mesodermal cells exhibiting a largely overlapping molecular signature [122]. These molecular signatures contain some hox genes $[122,123]$ but also genes such as piwi and vasa that are a part of the molecular signature of $P$. dumerilii germ cells $[25,62,122,124]$. This similarity of putative somatic stem cells and germ cells is consistent with the hypothesis of a common molecular signature of multipotency, also referred to as the Germline/Multipotency Program (GMP) [122, 125-129].

Platynereis dumerilii also harbors extensive regenerative capabilities during the extended juvenile phase [130]. Annelids are known as one of the highly regenerative metazoan taxa $[129,131,132]$. P. dumerilii, like other Nereididae, can regenerate complex body structures. Upon amputation of the posterior body (Fig. 6a), both differentiated structures of the pygidium and putative stem cells involved in posterior growth are regenerated. In 3- and 4-monthold worms, this process is a rapid event that follows a highly reproducible path and timeline, going through five specific stages in 5 days (Fig. 6b) [133]. Posterior regeneration relies on blastema formation and requires cell proliferation to proceed normally. Blastema cells express the GMP signature and likely mainly derive from a dedifferentiation process of cells next to the amputation plane [133]. Such extensive reprogramming of differentiated cells into proliferating progenitors or stem cells during regeneration may rely on epigenetic mechanisms such as DNA methylation and histone modifications [134] (Schenkelaars et al., in prep.). Posterior regeneration is then followed by post-regenerative posterior growth during which new segments bearing parapodia are formed [122, 133, 135]. In addition to posterior regeneration, parapodia regeneration following parapodia injury is known to be successful in $P$. dumerilii 


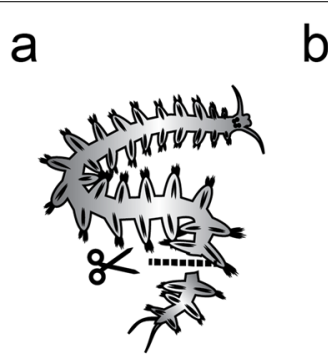

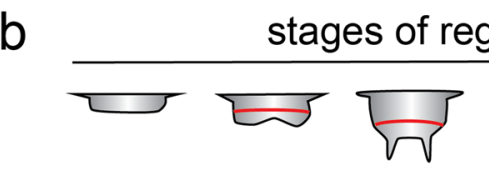

st. $1 \quad$ st. 2 st. $3 \quad$ st. 4

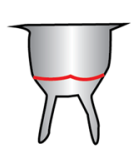

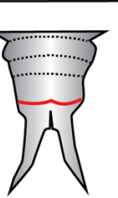

st.5

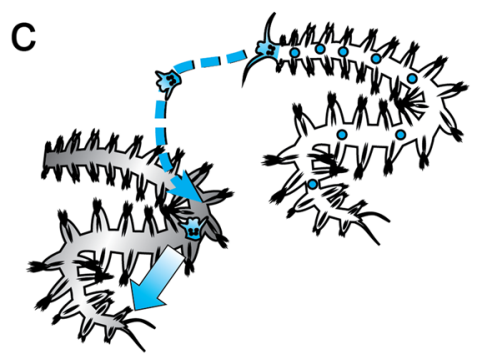

d

brain hormone activity

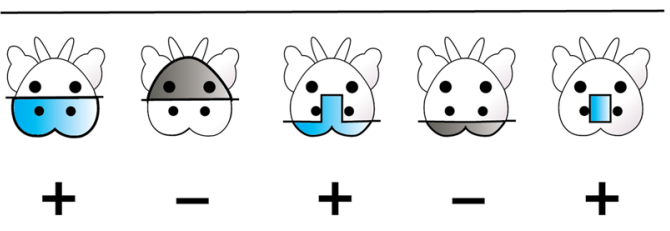

Fig. 6 Posterior regeneration as a paradigm for studying regenerative mechanisms and their regulation. a Experimental amputation of the posterior part of the body; b key stages (st.1-st.5) of posterior regeneration, re-establishing the growth zone (red), as well as molecular and morphological segment boundaries (dashed lines), reminiscent of the arrangements in posterior growth (right scheme). c Experimental paradigm establishing that transplanted juvenile heads produce a "brain hormone" endowing decerebrated individuals with the capacity to regenerate. d Exemplary results of brain grafts, charting the production of brain hormone (blue) to a medial region of the posterior brain. $\mathbf{b}$ Modified after Planques et al. 2019; d modified after Hofmann, 1976

(Velasquillo et al., in prep.). Future work will need to investigate the precise staging of this process, as well as the origin and contribution of cells. As posterior and parapodia regeneration include regeneration of many tissue and cell types such as stem cells, neurons, muscle, gut, and the germline, and thanks to the availability of transgenic tools (Additional file 1: Table S1 and Additional file 2: Table S2), P. dumerilii lends itself to be a powerful model to dissect the molecular and cellular mechanisms of regeneration.

Across animal phyla, regenerative capacities typically decline with developmental progress and age [136]. However, the underlying molecules and mechanisms remain largely unknown. Building on concepts developed in earthworms [137], the decline of regenerative capacity in $P$. dumerilii has been linked to changes in the levels of endocrine factors. Systematic transplantations (Fig. 6c) of brain pieces from donor individuals to decapitated hosts (unable to regenerate on their own) established that the responsible endocrine factors are produced in a distinct region of the $P$. dumerilii brain (Fig. 6d) [130]. These endocrine factors are collectively referred to as the annelid "brain hormone". Decline of brain hormone levels with age, or experimental decerebration of worms, abrogates regenerative capacity and posterior growth, and instead promotes sexual maturation. Biochemical fractionation of $P$. dumerilii head extracts revealed methylfarnesoate as a key component of the brain hormone [30]. The possibility to combine biochemical and genetic approaches makes $P$. dumerilii an attractive model for future research into the molecular mechanisms responsible for the modulation and gradual loss of regenerative capacity. In turn, these analyses will also open up possibilities to investigate broader aspects of age-dependent development, senescence, and ageing (Additional file 1: Table S1).

6. Platynereis gametogenesis and reproduction

Gametogenesis Platynereis dumerilii has 4 primordial germ cells (PGCs) that arise from the $4 \mathrm{~d}$ lineage during embryogenesis (Fig. 2). The 4 PGCs migrate anteriorly at the end of larval development, to the segment behind the jaws. These cells then start proliferating in this anterior region, a process that appears to be coupled with growth state and the number of total segments that the individuals have reached [25, $124,138,139]$. These cells are then thought to give rise to numerous gonial clusters that are found in the coelom and parapodia across the worm's trunk [26$28,124,138-140]$. Initially, the gonial clusters are 
not obviously different between males and females, but as gametogenesis progresses, maturing oocytes and sperm can be detected, even before the individuals start showing external morphological changes [26-28]. Thus, some cellular and biochemical aspects of oogenesis like vitellogenesis and spermatogenesis have been studied in more detail. As gametes grow floating in the coelomic body cavity, coelomic proteins have been one research focus-especially the production of yolk protein (vitellogenin) by a specialized coelomic cell type, the eleocytes. Other proteins such as lipoproteins, and gamete metabolism in general, remain less explored [141]. Similarly, the sex determination mechanisms are largely unknown in $P$. dumerilii. Empirical observations from lab cultures suggest genetic rather than environmental determination of sex. However, karyotyping has not revealed specific sex chromosomes [142].

Reproduction Prior to reproduction, $P$. dumerilii undergoes metamorphosis into the reproductive form (the heteronereis) that dies after the reproductive event (semelparity) with gametes shed into the water. Gametes in the water only remain fertilizable for a few minutes [143]. This requirement for highly synchronized reproduction makes $P$. dumerilii an ideal system to research the mechanisms underpinning the timing of the reproductive events as discussed in the chronobiology section [144, 145], including the use of chemosensory signals and the sex pheromones [144-146]. Understanding the complex timing of the reproductive mass-spawning events in the field requires studies into the environmental factors coordinating hormonal control of maturation [30, 147], and a mode of metamorphosis induction [148] that ensures a significant part of a population to be mature and available for a once in a lifetime spawning event. Timed by moon phase, time of night, and even weather conditions [144, 149], these worms commit to a single reproductive event at the water surface. The release of sex pheromones coordinates the reproductive behavior, including nuptial dance and the gamete release, as well as sperm-egg interaction cues [144]. Volatile ketones (5-methyl-3-heptanone) function as distance cues inducing rapid swimming that culminates in meeting of the sexual partners [146], albeit trail compounds such as the peptide cues in the related species Alitta (Nereis) succinea have not been identified in P. dumerilii [146]. The release of gametes follows pheromonal stimulation [150] through uric acid in males [146] and L-Ovothiol-A [151] in females. This last crucial step of the reproductive behavior is not as species specific: exposure to gamete-containing coelomic fluid of a large number of Nereidids induces heterospecific responses [152] with environmental timing of the reproductive events [153]. These chemical cues have also been shown to be used for aggressive mimicry by cone snails, which produce similar compounds to attract polychaete worms including Platynereis species as prey [154]. Future research directions will include the interconnection of gonadal maturation and precise reproductive timing synchronization within a population of worms, as well as the feedback regulation between maturation and regeneration.

\section{The Platynereis genome}

Platynereis dumerilii has 14 pairs of chromosomes $(2 n=28)[142,155]$. The current best estimates of the P. dumerilii genome lie between $\sim 1$ and 2 Gbp [142, 155-157]. Recent assemblies agree with this estimate and suggest $\sim 1.4 \mathrm{Gbp}$. The $P$. dumerilii genome shows considerable polymorphism, heterogeneity [156], and repeat content ( $\sim 43 \%$ of total nucleotides) with a CG ratio of $33.47 \%$ [158]. The presence of various haplotypes in a multitude of habitats make it an attractive model system to explore genotype-phenotype relationships and standing genetic variation. Current community sequencing efforts and advanced sequencing techniques will survey $P$. dumerilii genomic variability. Furthermore, short reads can also be mapped to a reasonable reference genome. This will be an exciting endeavor in the near future, given the interest to characterize the polymorphisms and heterogeneity to exploration of the genetics and genomics of not only $P$. dumerilii but also other Platynereis species. The mitochondrial genome of $P$. dumerilii has been sequenced [159]. Mitochondrial genome data is also available for other Platynereis species, as a basis for Platynereis species trees [159, 160]. Studies are also underway for sequencing genomes of sister Platynereis species such as P. massiliensis and $P$. megalops. Beyond the genome, various transcriptomic resources are available for specific developmental and life-cycle stages, body regions, and physiological phenomena $[65,114,161,162]$.

With the broad range of animal genomes available in the era of comparative genomics, it has become increasingly apparent that some animal genomes are unusual and distinctive, with plenty of lineagespecific gene gains/losses and rearrangements, while other genomes have evolved in a much more conservative fashion: they are less derived from an ancestral state such as the urbilaterian [163-167]. Based on current available data it appears that the 
genome of $P$. dumerilii falls into this latter lessderived category. As such, this annelid has been, and will likely continue to be, a member of an important group of species that will enable us to infer major features of ancient ancestral states that became the starting points for the evolution of large swathes of the animal kingdom.

Specific examples of this conservative genome evolution include the greater similarity of intron locations and abundance between $P$. dumerilii and vertebrates than was seen for more traditional invertebrate model species such as D. melanogaster and C. elegans [168]. Also, gene linkage, or synteny, appears relatively less derived from the urbilaterian condition than in fly and nematode, at least as indicated by the Antennapedia (ANTP)-class homeobox-containing genes, with their largely similar organization relative to chordates [169]. Similarly, P. dumerilii gene sequences appear to be relatively 'short branch' [168] and transcriptomes show a higher similarity of homologues with deuterostomes rather than ecdysozoans [64]. In addition, complements of gene families and composition of pathways show high levels of similarity to what is inferred for the bilaterian ancestor (or even earlier). P. dumerilii possesses 12 of the 13 ancient Wnt family members [74, 170] and a full complement of the frizzled-related genes that were inferred to be present in the urbilaterian [67]. P. dumerilii has both Retinoic Acid and Retinoid X Receptors (RAR and RXR) and the rest of the basic RA signaling pathway machinery $[171,172]$. Both the Notch receptor and many Delta and Jagged ligands, as well as the full signaling pathway machinery [173] and an extensive complement of putative target genes of the Hes superfamily [174] are also present. $P$. dumerilii has an ancestral complement of miRs that are deployed in various tissues [175] as well as neurogenic genes (including NeuroD and Churchill genes that are important in vertebrates but do not exist in Drosophila), neuropeptides, particularly G-proteincoupled receptors and neurotransmitter receptor pathways [161, 176-180], which have tended to become derived via secondary gene losses in other protostomes as well as some deuterostomes. As with several of these examples above, examining genetic mechanisms in $P$. dumerilii has led to revisions in our understanding of processes that at one time were thought to be specific to vertebrates but can now be inferred to have been present in the last common ancestor of vertebrates and annelids, such as complements of opsins in photoreception [92], estradiol signaling via 17- $\beta$-estradiol [181] or complements of immune-related genes [162].

As one would expect, there has also been some evolution of the genome structure and content along the lineage to $P$. dumerilii relative to the bilaterian ancestor, such as the initial stages of dispersal of the Hox and ParaHox gene clusters, in which single genes have broken away in both cases $[169,182]$. As a highquality assembly of the $P$. dumerilii genome sequence becomes available with chromosome-level resolution, further aspects of genome organization and evolution will be revealed, helping with a broader understanding of the general features of animal genome evolution and organization versus lineagespecific features.

\section{Platynereis as a model for ecology and toxicology}

Platynereis dumerilii is particularly abundant under organic pollution, therefore it is considered as a useful bioindicator species [183]. Based on the extensive use of Nereid polychaetes in ecotoxicological studies, Hutchinson et al. [184] evaluated $P$. dumerilii for its potential as an ecotoxicology model species to evaluate hazardous materials in the marine environment, and examined acute toxicity impacts of phenolic compounds on P. dumerilii larvae [185]. The genotoxicity of sewage effluents using Comet assays have also been studied but showed limited impacts of settled sewage upon larval stages [186]. Recent studies building on this demonstrated negative effects of halogenated and brominated disinfection byproducts found in sewage treatment works effluents [187]. In addition, toxicity of silver nanoparticles on early life stages, especially larvae, have been established [188]. Sublethal effects of volatile organic carbon from fuel oil induced male worms to shed gametes [189], highlighting the sublethal impacts of toxicants upon animal behavior [190].

Despite the ease of culturing and availability of the molecular, biochemical, and ecological data, $P$. dumerilii is still underused for ecotoxicology. In field studies, a problem related to the true distribution and ecology of this species arises by the fact that $P$. dumerilii, has a sibling species, P. massiliensis [37, 191] that is characterized by having a non-planktonic larval development (Fig. 7). Due to their similar morphologies at the juvenile and adult stages, only $P$. dumerilii is reported and $P$. massiliensis is not present in most ecological surveys in the Mediterranean Sea [192, 193]. Therefore, this sibling species has been largely overlooked [194], at least in the Mediterranean Sea, while it is better reported in northern Europe [195]. 


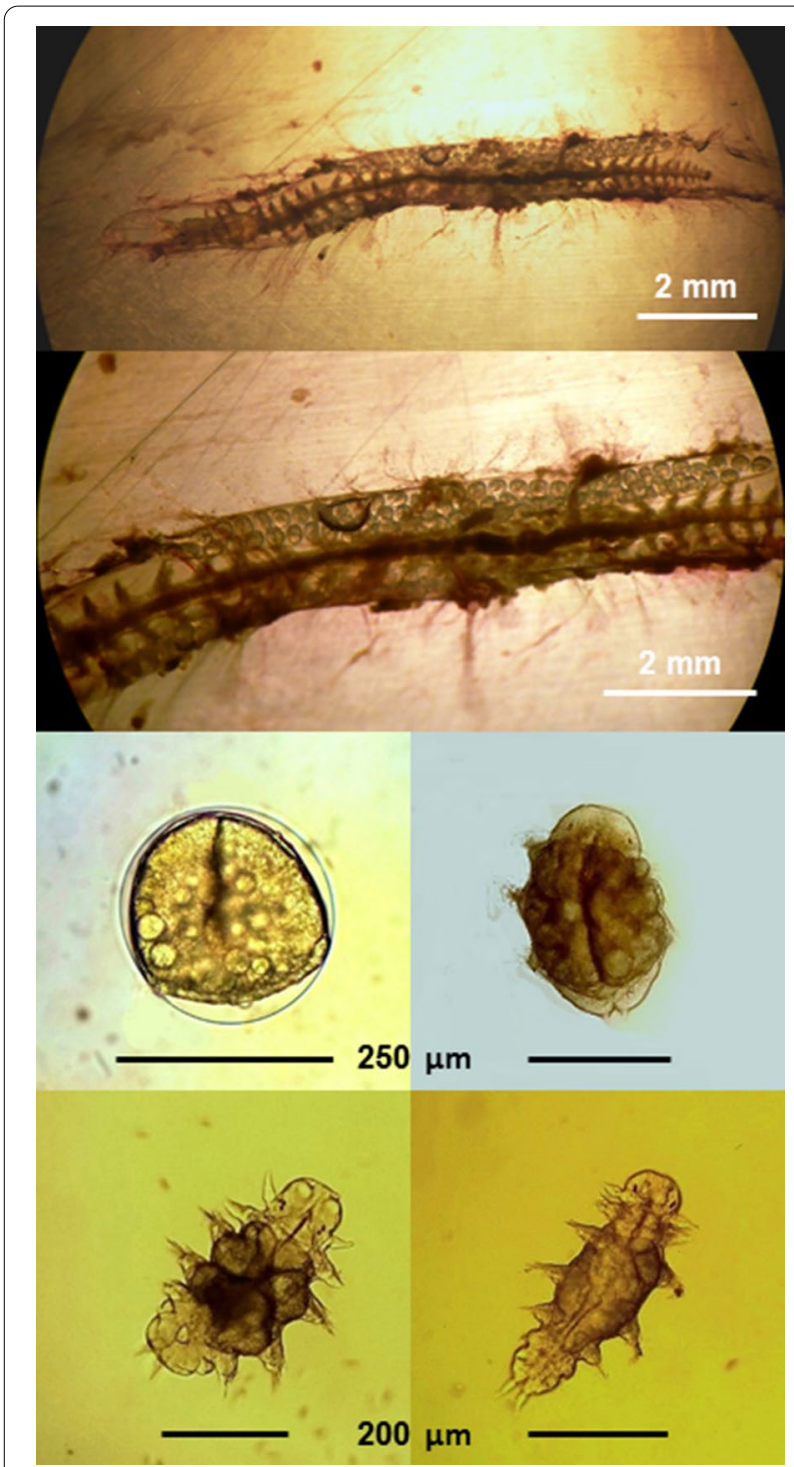

Fig. 7 A female specimen of Platynereis of massiliensis in reproduction, with the development of juveniles, from the population of the Vulcano island (Aeolian Archipelago, North Sicily) hydrothermal vent's system (from Waege et al., 2017, modified)

Recently, both sibling species, $P$. dumerilii and $P$. massiliensis, have been found with high abundance in the unique $\mathrm{CO} 2$ vent systems off the island of Ischia, where $\mathrm{CO} 2$ bubbling from the bottom is naturally acidifying the surrounding water [196-199]. Worms from this habitat show specific eco-physiological adaptations, including distinct responses to chemical stimuli mediated by ocean acidification [196, 200, 201]. These sites have largely been utilized as a natural laboratory to study the effects of ocean acidification on the benthic biota, since the $\mathrm{pH}$ and carbonate chemistry conditions are simulating the further acidification scenarios of the global oceans for the end of the century [202]. Analyses showed the occurrence of multiple differential genotypes, suggesting the presence of other cryptic species, for both siblings $P$. dumerilii and $P$. massiliensis [3] (Fig. 8). P. massiliensis was also found associated to the hydrothermal vents off the islands of Vulcano and Panarea (Aeolian Archipelago, north Sicily) (Fig. 8), with different cryptic species associated to each unique vent's systems [3] (Gambi M.C., unpublished) (Fig. 7).

These findings open questions about the taxonomic identity of both sibling species and on speciation within them, due to unique environmental conditions, such as those occurring at the hydrothermal vents. Only studies that included individuals bred in the laboratory or using metamorphosed heteronereids enable the distinction between the sibling species. Nevertheless, both sibling species of Platynereis seem to be ideal models to understand the potential for acclimation/adaptation to climate stressors, also throughout multigenerational studies. The use of a well-studied model species such as P. dumerilii represents an ideal opportunity to link the mechanistic understanding of the impacts and physiological costs of changing climate, including changes in water carbonate chemistry, upon functional traits with ecological endpoints including survival, fitness and reproductive success. For example, ocean acidification is known to alter animal behavior [203], cause changes to signaling molecules [204] and alter neurotransmission [205]. Studies using P. dumerilii could shed light on both the mechanisms and consequences including costliness of adaptation to environmental change.

\section{Experimental approaches}

From genome editing and stable transgenesis to bioinformatics, single-cell RNA-sequencing, single cell atlases, and behavioral assays, $P$. dumerilii has many fundamental and cutting-edge techniques available and established. Application examples for many techniques are covered above in the context of the scientific questions addressed. In addition, we also provide a comprehensive table listing methods, relevant example references, noteworthy limitations, efficiencies and possible future directions (Additional file 1: Table S1). The techniques are discussed in detail in the referenced literature.

(See figure on next page.)

Fig. 8 The phylogeographic tree of Platynereis dumerilii and P. massiliensis based on COI analyses (From Waege et al. 2017, modified). Clade 1 and clade 2 represent siblings of P. massiliensis at Ischia (blue dot) and Vulcano (orange dots) vents; clade 3 and clade 4 represent siblings of $P$. dumerilii, grouped without a clear geographic pattern 


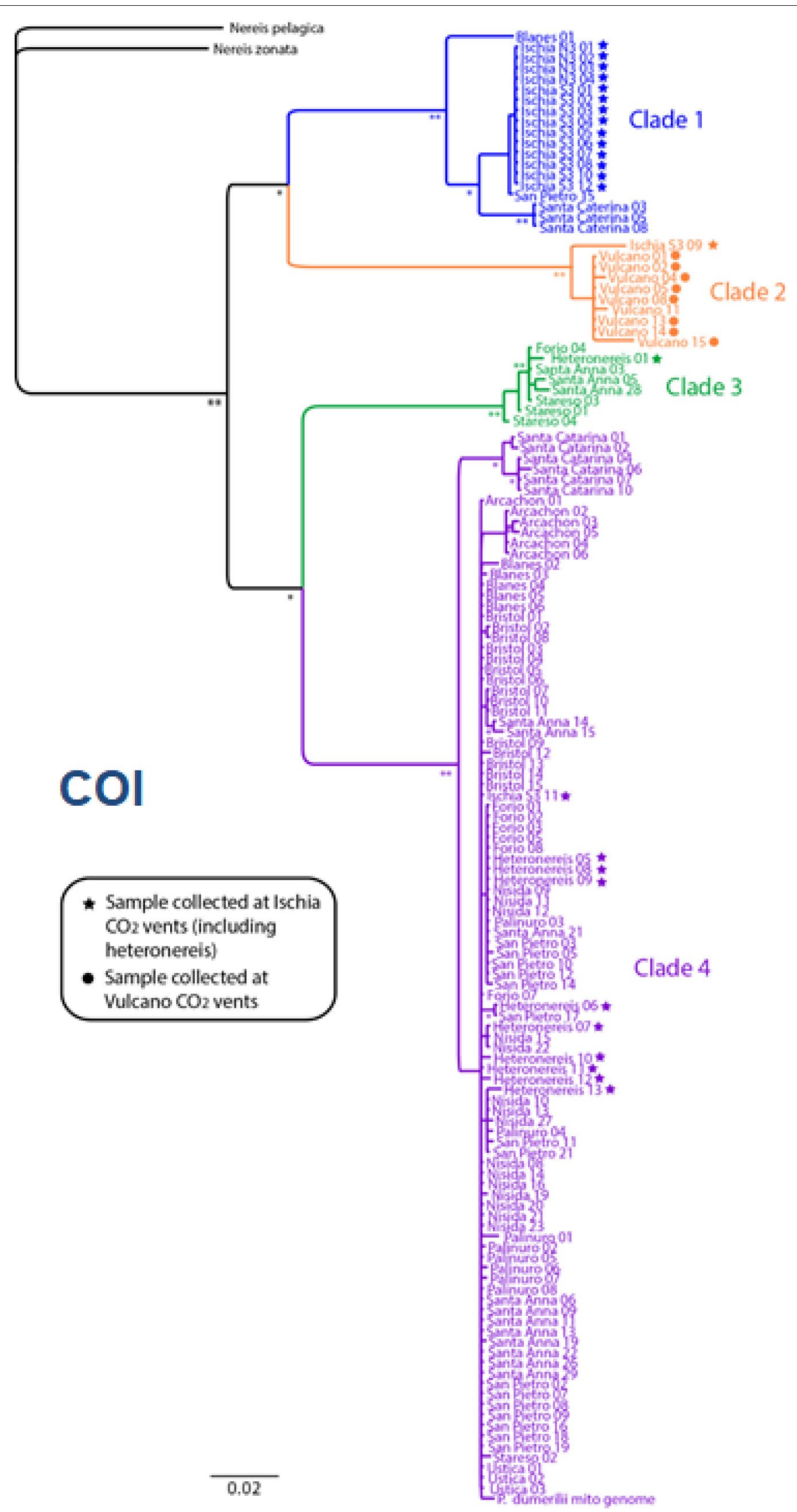

Fig. 8 (See legend on previous page.) 
Multiple transgenic and inbred lines are hosted by individual labs and are shared within the community (Additional file 2: Table S2). Additional resources include the sequenced genome and transcriptomes (Additional file 1: Table S1) [64, 65]. Furthermore, a cellular gene expression atlas and a whole-body connectome with synaptic resolution are accessible via the Platybrowser [206] and CATMAID [207], respectively.

\section{Research community and resources}

The Platynereis community has been growing over the last few decades. Currently, about 15 Platynereis labs are studying a broad range of research topics, including development, evolution, regeneration, chronobiology, and neurobiology. Last year, the first Platynereis conference was organized, resulting in the formation of several working groups to address challenges and encourage collaborations in the community. One outcome has been the community website [208], which includes key information about the Platynereis community and existing resources.

The growing and interactive community of the Nereid welcomes other scientists to join us in the exciting journey of exploring the biology of this animal. Platynereis is now a mature experimental system with transgenesis, knockouts, genomic resources, gene-expression atlases and a full connectome, and progress can be made rapidly to gain mechanistic and molecular insights into developmental, physiological or neuronal processes and also ecological interactions. There are many open questions ranging from evo-devo through neurobiology, to biophysics and endless possibilities for technology development. In this review, we tried to give an overview of the broad and often unique biological questions that can now be addressed in Platynereis and the increasing experimental power of the system. The time is ripe to switch to the Nereid.

\section{Supplementary Information}

The online version contains supplementary material available at https://doi. org/10.1186/s13227-021-00180-3.

Additional file 1: Table S1. List of techniques.

Additional file 2: Table S2. List of available wild-type and mutant strains.

\section{Acknowledgements}

We thank the reviewers and editors for their feedback and comments that improved this manuscript.

\section{Authors' contributions}

Everyone who has contributed to this manuscript text and figures is listed as an author. All authors read and approved the final manuscript.
Funding

Funding resources are shown after author initials.

EAW: BBSRC David Phillips Fellowship BB/T00990X/1. BDÖ: NIH NIGMS MIRA 1R35GM138008-01; NSF-EDGE Award no 1923429; Hibbitt Startup Funds. GJ, LABC, CH: Wellcome Trust Investigator Award 214337/Z/18/Z. KNM: Marie Sklodowska-Curie fellow supported by the European Union's Horizon 2020 research and innovation programme under grant agreement No. 766053, project EvoCELL. NR: European Union Horizon 2020, Marie Skłodowska-Curie Grant No 838225. MCG: Stazione Zoologica A. Dohrn (Napoli) and the Ischia Marine Center technical staff; Open University PhD programme; ASSEMBLE; PON-MODO project (Campania Region, Italy), RITMARE - Flag project, Italy; MARES Consortium. Thanks to the ECCSEL - NatLab Italy facilities, managed by the OGS (Trieste), to support collection at Panarea and Vulcano islands. JDH: NERC award NE/T001577/1. MHT: Deutsche Forschungsgemeinschaft (DFG), Grant Number TO563/7-1. EG and MV: Labex 'Who Am I?' (No. ANR-11-LABX-0071) funded by the French Government through its 'Investments for the Future' program operated by the ANR under Grant No. ANR-11-IDEX-0005-01, Centre National de la Recherche Scientifique (DBM Grant), Université de Paris (IDEX Emergence grant 2020), Agence Nationale de la Recherche (Grant TELOBLAST no. ANR-16-CE91-0007; Grant STEM No. ANR-19-CE27-0027-02), the «Association pour la Recherche sur le Cancer» (Grant PJA 20191209482), and the «Ligue Nationale Contre le Cancer» (Grant RS20/75-20). SQS: NSF (US) Award IOS-1455185, MOST (TW) 108-2311-B-001002-MY3, Academia Sinica Career Development Award AS-CDA-110-L02, and the Institute of Cellular and Organismic Biology (ICOB) of Academia Sinica (TW). YWH: Deutsche Forschungsgemeinschaft (DFG), grant number TO563/7-1 (to Pavel Tomancak). OS: Austrian Science Fund Grant P32190. GB: The Balavoine Lab was funded by the CNRS, the Université de Paris and grants from the ANR (TELOBLAST no. ANR-16-CE91-0007) and from the ARC (PJA 20181208248). FR and KTR: The research leading to these results has received funding from the European Research Council under the European Community's Seventh Framework Programme (FP7/2007-2013)/ERC Grant Agreement 260304 (F.R.) and ERC Grant Agreement 337011 (K.T.-R.); the Horizon 2020 Programme ERC Grant Agreement 81995 (K.T.-R.); the research platforms 'Rhythms of Life' (K.T.-R., F.R.) and "Single-cell genomics of stem cells" (F.R.) of the University of Vienna; the Austrian Science Fund (FWF) START award, project Y413 (K.T.-R.); the Austrian Science Fund (FWF) projects P28970 (K.T.-R.) and 12972 (F.R.); the Austrian Science Fund (FWF) grant F78 (K.T.-R., F.R.). DA and PB ERC Advanced grant NeuralCellTypeEvo \#788921.

Availability of data and materials

Not applicable.

\section{Declarations}

Ethics approval and consent to participate

Not applicable.

Consent for publication

Not applicable.

Competing interests

The authors declare that they have no competing interests.

\section{Author details}

${ }^{1}$ Eugene Bell Center for Regenerative Biology and Tissue Engineering, Marine Biological Laboratory, Woods Hole, MA 02543, USA. ²Department of Zoology, University of Cambridge, Downing Street, Cambridge CB2 3EJ, UK. ${ }^{3}$ Biosciences, College of Life and Environmental Sciences, University of Exeter, Exeter, UK. ${ }^{4}$ Living Systems Institute, University of Exeter, Stocker Road, Exeter, UK. ${ }^{5}$ Max Perutz Labs, University of Vienna, Dr. Bohr-Gasse 9/4, 1030 Vienna, Austria. ${ }^{6}$ Institut Jacques Monod, University of Paris/CNRS, 15 rue Hélène Brion, 75013 Paris, France. ${ }^{7}$ European Molecular Biology Laboratory, Developmental Biology Unit, Meyerhofstrasse 1, 69117 Heidelberg, Germany. ${ }^{8}$ Gatty Marine Laboratory, The Scottish Oceans Institute, University of St Andrews, East Sands, St Andrews, Fife KY16 8LB, UK. ${ }^{9}$ National Institute of Oceanography and Applied Geophysics - OGS, Trieste, Italy. ${ }^{10}$ Max Planck Institute of Molecular Cell Biology and Genetics, Pfotenhauerstraße 108, 01307 Dresden, Germany. ${ }^{11}$ Department of Biological \& Marine Sciences, Hull University, Cottingham Road, Hull HU67RX, UK. ${ }^{12}$ School of Life Sciences, Simon F.S. Li Marine 
Science Laboratory, State Key Laboratory of Agrobiotechnology, The Chinese University of Hong Kong, Hong Kong, China. ${ }^{13}$ Institute of Cellular and Organismic Biology, Academia Sinica, No. 128, Sec. 2, Academia Road, Nankang, Taipei 11529, Taiwan. ${ }^{14}$ Department for Neurosciences and Developmental Biology, University of Vienna, Vienna, Austria. ${ }^{15}$ Sainsbury Wellcome Centre for Neural Circuits and Behaviour, Howland Street 25, London W1T 4JG, UK. ${ }^{16}$ Centre for Organismal Studies (COS), University of Heidelberg, 69120 Heidelberg, Germany.

Received: 2 June 2021 Accepted: 20 August 2021

Published online: 27 September 2021

\section{References}

1. Ocean Biodiversity Information System. https://obis.org/. Accessed 2 Apr 2021.

2. Teixeira MAL, Nygren A, Ravara A, Vieira PE, Hernández JC, Costa FO. The small polychaete Platynereis dumerilii revealed as a large species complex with fourteen MOTUs in European marine habitats. Eur Surg. 2021;3(4):e64937.

3. Wäge J, Valvassori G, Hardege JD, Schulze A, Gambi MC. The sibling polychaetes Platynereis dumerilii and Platynereis massiliensis in the Mediterranean Sea: are phylogeographic patterns related to exposure to ocean acidification? Mar Biol. 2017;164(10):199.

4. Kisseleva MI. Dynamique et production de la population de Polychète Platynereis dumerilii dans la biocoenose de la Cystoseira en Mer Noire. "Grigore Antipa."Trav Mus Natl Hist Nat Grigore Antipa. 1971;11:49-58.

5. Popa LO, Popa OP, Krapal A-M, lorgu El, Surugiu V. Fine-scale population genetics analysis of Platynereis dumerilii (Polychaeta, Nereididae) in the Black Sea: how do local marine currents drive geographical differentiation? J Exp Zool A Ecol Genet Physiol. 2014;321 (1):41-7.

6. Bellan G. Contribution à l'étude systématique, bionomique et écologique des Annélides Polychètes de la Méditerranée [Internet]. [Gap]: Louis-Jean; 1964. https://www.worldcat.org/title/contribution-aletude-systematique-bionomique-et-ecologique-des-annelides-polyc hetes-de-la-mediterranee/oclc/601454852

7. Giangrande A. Polychaete zonation and its relation to algal distribution down a vertical cliff in the western Mediterranean (Italy): a structural analysis. J Exp Mar Bio Ecol. 1988;120(3):263-76.

8. Giangrande A, Fraschetti S, Terlizzi A. Local recruitment differences in Platynereis dumerilii (Polychaeta, Nereididae) and their consequences for population structure. Ital J Zool. 2002;69(2):133-9.

9. Sarda R. Polychaete communities related to plant covering in the médiolittoral and infralittoral zones of the Balearic islands (western méditerranean). Mar Ecol. 1991;12(4):341-60.

10. Gambi MC, Lorenti M, Russo GF, Scipione MB, Zupo V. Depth and seasonal distribution of some groups of the vagile fauna of the Posidonia oceanica leaf stratum: structural and trophic analyses. Mar Ecol. 1992:13(1):17-39.

11. Scipione MB, Gambi MC, Lorenti M. Vagile fauna of the leaf stratum of Posidonia oceanica and Cymodocea nodosa in the Mediterranean Sea. In: Kuo J, Phillips RC, Walker DI, Kirkman H, editors. Seagrass Biology. 1996, 249-60.

12. Daly JM. Behavioural and secretory activity during tube construction by Platynereis dumerilii Aud \& M. Edw. [Polychaeta: Nereidae]. J Mar Biol Assoc U K. 1973;53(3):521-9.

13. Gambi MC, Zupo V, Buia MC, Mazzella L. Feeding ecology of Platynereis dumerilii (Audouin \& Milne-Edwards) in the seagrass Posidonia oceanica system: the role of the epiphytic flora (Polychaeta, Nereididae). Ophelia. 2000:53(3):189-202.

14. Hempelmann F. Zur Naturgeschichte von Nereis dumerilii. Aud et Edw Zoologica. 1911;25:1-135.

15. Lanera P, Gambi MC. Polychaete distribution in some Cymodocea nodosa meadows around the Island of Ischia (Gulf of Naples Italy). Oebalia. 1993;19:89-103.

16. Gambi MC, Giangrande A, Martinelli M, Chessa L. Polychaetes of a Posidonia oceanica bed off Sardinia (Italy): spatio-temporal distribution and feeding guild analysis. Sci Mar. 1995;59(2):129-41.

17. Bedford AP, Moore PG. Macrofaunal involvement in the sublittoral decay of kelp debris: the polychaete Platynereis dumerilii (Audouin and Milne-Edwards) (Annelida: Polychaeta). Estuar Coast Shelf Sci. 1985;20(2):117-34.

18. Grant A. The reproductive cycle of Platynereis dumerilii (audouin \& milneedwards) (polychaeta: nereidae) from the firth of clyde. Sarsia. 1989;74(2):79-84

19. Jacobs RPWM, Pierson ES. Zostera marina spathes as a habitat for Platynereis dumerilii (Audouin and Milne-Edwards, 1834). Aquat Bot. 1979;1(6):403-6.

20. Zantke J, Ishikawa-Fujiwara T, Arboleda E, Lohs C, Schipany K, Hallay N, et al. Circadian and circalunar clock interactions in a marine annelid. Cell Rep. 2013;5(1):99-113.

21. Fischer A, Dorresteijn A. The polychaete Platynereis dumerilii (Annelida): a laboratory animal with spiralian cleavage, lifelong segment proliferation and a mixed benthic/pelagic life cycle. BioEssays. 2004;26(3):314-25.

22. Fischer $\mathrm{AH}$, Henrich T, Arendt D. The normal development of Platynereis dumerilii (Nereididae, Annelida). Front Zool. 2010;30(7):31.

23. Hauenschild C, Fischer A. Platynereis dumerilii: mikroskopische Anatomie, Fortpflanzung, Entwicklung. Stuttgart: G. Fischer; 1969. (Grosses zoologisches Praktikum, 10b).

24. Fischer A. Reproduction and postembryonic development of the annelid Platynereis dumerilii. Film C. 1985;1577.

25. Kuehn E, Clausen DS, Null RW, Metzger BM, Willis AD, Özpolat BD. Segment number threshold determines juvenile onset of germline cluster proliferation in Platynereis dumerilii. bioRxiv. 2021. https://doi.org/10 1101/2021.04.22.439825v1.

26. Meisel J. Zur Hormonabhängigkeit der Spermatogenese bei Platynereis dumerilii: licht-und elektronenmikroskopische Befunde sowie experimentelle Untersuchungen in vivo und in vitro. na; 1990.

27. Fischer A. Stages and stage distribution in early oogenesis in the Annelid, Platynereis dumerilii. Cell Tissue Res. 1974;156(1):35-45.

28. Fischer A. The structure of symplasmic early oocytes and their enveloping sheath cells in the polychaete, Platynereis dumerilii. Cell Tissue Res. 1975;160(3):327-43

29. Andreatta G, Broyart C, Borghgraef C, Vadiwala K, Kozin V, Polo A, et al. Corazonin signaling integrates energy homeostasis and lunar phase to regulate aspects of growth and sexual maturation in Platynereis. Proc Natl Acad Sci U S A. 2020. https://doi.org/10.1073/pnas.1910262116.

30. Schenk S, Krauditsch C, Frühauf P, Gerner C, Raible F. Discovery of methylfarnesoate as the annelid brain hormone reveals an ancient role of sesquiterpenoids in reproduction. Elife. 2016. https://doi.org/10.7554/ eLife.17126.

31. Korringa P. Relations between the moon and periodicity in the breeding of marine animals. Ecol Monogr. 1947;17(3):347-81.

32. Giangrande A. Cicli vitali dei policheti e relazioni con l'ambiente. Oebalia. 1989;15:157-67.

33. Bleidorn C. Recent progress in reconstructing lophotrochozoan (spiralian) phylogeny. Org Divers Evol. 2019. https://doi.org/10.1007/ s13127-019-00412-4.

34. Marlétaz F, Peijnenburg KTCA, Goto T, Satoh N, Rokhsar DS. A new spiralian phylogeny places the enigmatic arrow worms among Gnathiferans. Curr Biol. 2019. https://doi.org/10.1016/j.cub.2018.11.042.

35. Hempelmann F. Zur Naturgeschichte von Nereis dumerilii Aud. et Edw. 1911 Jan 1; https://www.schweizerbart.de/publications/detail/artno/ 169006200/Zur_Naturgeschichte_von_Nereis_dumerilii_Aud_et_Edw. Accessed 15 Feb 2021.

36. Hauenschild C. Nachweis der sogenannten atoken Geschlechtsform des Polychaeten Platynereis dumerilii Aud. et M. Edw. als eigene Art auf Grund von Zuchtversuchen. Nachdruck verboten Ubersetzungsr Vor. 1951;107-28.

37. Moquin-Tandon G. Note sur une nouvelle annelide chetopode hermaphrodite (Nereis massiliensis). Ann Sci Nat. 1869:5(11):134.

38. Hauenschild C. Uber das lunarperiodische Schwarmen von Platynereis dumerilii in Laboratoriumszuchten. Naturwissenschaften. 1954;41:5567. https://doi.org/10.1007/bf00629049.

39. Hauenschild C. Lunar periodicity. Cold Spring Harb Symp Quant Biol. 1960;25:491-7.

40. Fischer A, editor. The Helgoland Manual of Animal Development: Notes and Laboratory Protocols on Marine Invertebrates. Pfeil, Dr. Friedrich; 2013. 
41. Kuehn E, Stockinger AW, Girard J, Raible F, Özpolat BD. A scalable culturing system for the marine annelid Platynereis dumerilii. PLOS ONE. 2019;14(12):e0226156

42. Olive PJW, Wang WB. Cryopreservation of Nereis virens (Polychaeta, Annelida) Larvae: the mechanism of cryopreservation of a differentiated metazoan. Cryobiology. 1997;34(3):284-94.

43. Just EE. Breeding habits of the heteronereis form of Platynereis megalops at Woods Hole. Mass Biol Bull. 1914;27(4):201-12.

44. Henry JQ. Spiralian model systems. Int J Dev Biol. 2014;58:389-401.

45. Sulston JE, Schierenberg E, White JG, Thomson JN. The embryonic cell lineage of the nematode Caenorhabditis elegans. Dev Biol. 1983;100(1):64-119.

46. Nishida $\mathrm{H}$, Satoh N. Cell lineage analysis in ascidian embryos by intracellular injection of a tracer enzyme. II. The 16- and 32-cell stages. Dev Biol. 1985;110(2):440-54

47. Nishida $\mathrm{H}$, Stach $\mathrm{T}$. Cell lineages and fate maps in tunicates: conservation and modification. Zoolog Sci. 2014;31(10):645-52.

48. Sternberg PW, Félix MA. Evolution of cell lineage. Curr Opin Genet Dev. 1997;7(4):543-50.

49. Guignard L, Fiúza U-M, Leggio B, Laussu J, Faure E, Michelin G, et al. Contact area-dependent cell communication and the morphological invariance of ascidian embryogenesis. Science. 2020. https://doi.org/10. 1126/science.aar5663.

50. Lambert JD. Developmental patterns in spiralian embryos. Curr Biol. 2010;20(2):R72-7.

51. Hejnol A. A twist in time-the evolution of spiral cleavage in the light of animal phylogeny. Integr Comp Biol. 2010;50(5):695-706.

52. Martín-Durán JM, Marlétaz F. Unravelling spiral cleavage. Development. 2020. https://doi.org/10.1242/dev.181081.

53. Wilson EB. The cell-lineage of Nereis. A contribution to the cytogeny of the annelid body. J Morphol. 1892;6(3):361-480.

54. Ackermann C, Dorresteijn A, Fischer A. Clonal domains in postlarval Platynereis dumerilii (Annelida: Polychaeta). J Morphol. 2005;266(3):258-80.

55. Dorresteijn AWC. Quantitative analysis of cellular differentiation during early embryogenesis of Platynereis dumerilii. Rouxs Arch Dev Biol. 1990;199(1):14-30.

56. Schneider S, Fischer A, Dorresteijn AWC. A morphometric comparison of dissimilar early development in sibling species of Platynereis (Annelida, Polychaeta). Rouxs Arch Dev Biol. 1992;201(4):243-56.

57. Fischer AHL, Arendt D. Mesoteloblast-like mesodermal stem cells in the polychaete annelid Platynereis dumerilii (Nereididae). J Exp Zool B Mol Dev Evol. 2013;320(2):94-104.

58. Just EE. The morphology of normal fertilization in Platynereis megalops. J Morphol. 1915;26(2):217-33.

59. Kluge B, Lehmann-Greif M, Fischer A. Long-lasting exocytosis and massive structural reorganisation in the egg periphery during cortical reaction in Platynereis dumerilii (Annelida, Polychaeta). Zygote. 1995;3(2):141-56.

60. Özpolat BD, Handberg-Thorsager M, Vervoort M, Balavoine G. Cell lineage and cell cycling analyses of the $4 \mathrm{~d}$ micromere using live imaging in the marine annelid platynereis dumerilii. Elife. 2017. https://doi.org/10. 7554/elife.30463.

61. Achim K, Eling N, Vergara HM, Bertucci PY, Musser J, Vopalensky P, et al. Whole-body single-cell sequencing reveals transcriptional domains in the annelid larval body. Mol Biol Evol. 2018;35(5):1047-62.

62. Rebscher N, Lidke AK, Ackermann CF. Hidden in the crowd: primordial germ cells and somatic stem cells in the mesodermal posterior growth zone of the polychaete Platynereis dumerilii are two distinct cell populations. EvoDevo. 2012;18(3):9.

63. Vopalensky P, Tosches MA, Achim K, Handberg-Thorsager M, Arendt D. From spiral cleavage to bilateral symmetry: the developmental cell lineage of the annelid brain. BMC Biol. 2019;17(1):81.

64. Chou H-C, Pruitt MM, Bastin BR, Schneider SQ. A transcriptional blueprint for a spiral-cleaving embryo. BMC Genomics. 2016;5(17):552.

65. Chou H-C, Acevedo-Luna N, Kuhlman JA, Schneider SQ. PdumBase: a transcriptome database and research tool for Platynereis dumerilii and early development of other metazoans. BMC Genomics. 2018;19(1):618.
66. Levin M, Anavy L, Cole AG, Winter E, Mostov N, Khair S, et al. The middevelopmental transition and the evolution of animal body plans. Nature. 2016;531(7596):637-41.

67. Bastin BR, Chou H-C, Pruitt MM, Schneider SQ. Structure, phylogeny, and expression of the frizzled-related gene family in the lophotrochozoan annelid Platynereis dumerilii. EvoDevo. 2015;4(6):37.

68. Marioni JC, Arendt D. How single-cell genomics is changing evolutionary and developmental biology. Annu Rev Cell Dev Biol. 2017:6(33):537-53.

69. Nakama AB, Chou H-C, Schneider SQ. The asymmetric cell division machinery in the spiral-cleaving egg and embryo of the marine annelid Platynereis dumerilii. BMC Dev Biol. 2017;17(1):16.

70. Hsieh Y-W. Cellular, Cytoskeletal, and Biophysical Mechanisms of Spiral Cleavage during Platynereis dumerilii Embryogenesis [Internet] [PhD]. Tomancak P, editor. Technische Universität Dresden; 2020. https://tud.qucosa.de/api/qucosa\%3A72836/attachment/ATT-0/

71. Dorresteijn AWC, Eich P. Experimental change of cytoplasmic composition can convert determination of blastomeres in Platynereis dumerilii (Annelida, Polychaeta). Rouxs Arch Dev Biol. 1991;200(6):342-51.

72. Dorresteijn AWC, Bornewasser $\mathrm{H}$, Fischer A. A correlative study of experimentally changed first cleavage and Janus development in the trunk of Platynereis dumerilii (Annelida, Polychaeta). Rouxs Arch Dev Biol. 1987;196(1):51-8.

73. Schneider SQ, Bowerman B. beta-Catenin asymmetries after all animal/vegetal- oriented cell divisions in Platynereis dumerilii embryos mediate binary cell-fate specification. Dev Cell. 2007;13(1):73-86.

74. Pruitt MM, Letcher EJ, Chou H-C, Bastin BR, Schneider SQ. Expression of the wnt gene complement in a spiral-cleaving embryo and trochophore larva. Int J Dev Biol. 2014;58(6-8):563-73.

75. Pfeifer K, Schaub C, Domsch K, Dorresteijn A, Wolfstetter G. Maternal inheritance of twist and analysis of MAPK activation in embryos of the polychaete annelid Platynereis dumerilii. PLoS ONE. 2014. https:// doi.org/10.1371/journal.pone.0096702.

76. Marlow H, Tosches MA, Tomer R, Steinmetz PR, Lauri A, Larsson T, et al. Larval body patterning and apical organs are conserved in animal evolution. BMC Biol. 2014;29(12):7.

77. Williams EA, Verasztó C, Jasek S, Conzelmann M, Shahidi R, Bauknecht $P$, et al. Synaptic and peptidergic connectome of a neurosecretory center in the annelid brain. Elife. 2017. https://doi.org/10.7554/eLife. 26349.

78. Tessmar-Raible K, Raible F, Christodoulou F, Guy K, Rembold M, Hausen $\mathrm{H}$, et al. Conserved sensory-neurosecretory cell types in annelid and fish forebrain: insights into hypothalamus evolution. Cell. 2007;129(7):1389-400.

79. Arendt D, Technau U, Wittbrodt J. Evolution of the bilaterian larval foregut. Nature. 2001;409(6816):81-5.

80. Nielsen C. How did indirect development with planktotrophic larvae evolve? Biol Bull. 2009;216(3):203-15.

81. Jékely G, Colombelli J, Hausen H, Guy K, Stelzer E, Nédélec F, et al. Mechanism of phototaxis in marine zooplankton. Nature. 2008;456(7220):395-9.

82. Bezares-Calderón LA, Berger J, Jasek S, Verasztó C, Mendes S, Gühmann $\mathrm{M}$, et al. Neural circuitry of a polycystin-mediated hydrodynamic startle response for predator avoidance. Elife. 2018. https://doi.org/10.7554/ eLife.36262

83. Tosches MA, Bucher D, Vopalensky P, Arendt D. Melatonin signaling controls circadian swimming behavior in marine zooplankton. Cell. 2014;159(1):46-57.

84. Conzelmann M, Offenburger S-L, Asadulina A, Keller T, Münch TA, Jékely G. Neuropeptides regulate swimming depth of Platynereis larvae. Proc Natl Acad Sci USA. 2011;108(46):E1174-83.

85. Verasztó C, Ueda N, Bezares-Calderón LA, Panzera A, Williams EA, Shahidi $\mathrm{R}$, et al. Ciliomotor circuitry underlying whole-body coordination of ciliary activity in the larva. Elife. 2017. https://doi.org/10.7554/eLife. 26000.

86. Randel N, Bezares-Calderón LA, Gühmann M, Shahidi R, Jékely G. Expression dynamics and protein localization of rhabdomeric opsins in Platynereis larvae. Integr Comp Biol. 2013;53(1):7-16.

87. Ayers T, Tsukamoto H, Gühmann M, Veedin Rajan VB, Tessmar-Raible K. A G-type opsin mediates the shadow reflex in the annelid Platynereis dumerilii. BMC Biol. 2018;16(1):41. 
88. Gühmann M, Jia H, Randel N, Verasztó C, Bezares-Calderón LA, Michiels NK, et al. Spectral tuning of phototaxis by a Go-Opsin in the rhabdomeric eyes of Platynereis. Curr Biol. 2015;25(17):2265-71.

89. Backfisch B, Veedin Rajan VB, Fischer RM, Lohs C, Arboleda E, TessmarRaible K, et al. Stable transgenesis in the marine annelid Platynereis dumerilii sheds new light on photoreceptor evolution. Proc Natl Acad Sci USA. 2013;110(1):193-8.

90. Verasztó C, Gühmann M, Jia H, Rajan VBV, Bezares-Calderón LA, PiñeiroLopez C, et al. Ciliary and rhabdomeric photoreceptor-cell circuits form a spectral depth gauge in marine zooplankton. Elife. 2018. https://doi. org/10.7554/eLife.36440.

91. Tsukamoto H, Chen I-S, Kubo Y, Furutani Y. A ciliary opsin in the brain of a marine annelid zooplankton is ultraviolet-sensitive, and the sensitivity is tuned by a single amino acid residue. J Biol Chem. 2017;292(31):12971-80.

92. Arendt D, Tessmar-Raible K, Snyman H, Dorresteijn AW, Wittbrodt J. Ciliary photoreceptors with a vertebrate-type opsin in an invertebrate brain. e-Neuroforum. 2005. https://doi.org/10.1515/nf-2005-0106.

93. Conzelmann M, Jékely G. Antibodies against conserved amidated neuropeptide epitopes enrich the comparative neurobiology toolbox. EvoDevo. 2012;3(1):23.

94. Conzelmann M, Williams EA, Tunaru S, Randel N, Shahidi R, Asadulina $A$, et al. Conserved MIP receptor-ligand pair regulates Platynereis larval settlement. Proc Natl Acad Sci USA. 2013;110(20):8224-9.

95. Randel N, Asadulina A, Bezares-Calderón LA, Verasztó C, Williams EA, Conzelmann $\mathrm{M}$, et al. Neuronal connectome of a sensory-motor circuit for visual navigation. Elife. 2014. https://doi.org/10.7554/eLife.02730.

96. Chartier TF, Deschamps J, Dürichen W, Jékely G, Arendt D. Whole-head recording of chemosensory activity in the marine annelid Platynereis dumerilii. Open Biol. 2018;8:180139. https://doi.org/10.1098/rsob. 180139.

97. Williams EA, Conzelmann M, Jékely G. Myoinhibitory peptide regulates feeding in the marine annelid Platynereis. Front Zool. 2015;12(1):1.

98. Hadfield MG, Meleshkevitch EA, Boudko DY. The apical sensory organ of a gastropod veliger is a receptor for settlement cues. Biol Bull. 2000;198(1):67-76.

99. Brunet T, Fischer AH, Steinmetz PR, Lauri A, Bertucci P, Arendt D. The evolutionary origin of bilaterian smooth and striated myocytes. Elife. 2016. https://doi.org/10.7554/eLife.19607.

100. Lauri A, Brunet T, Handberg-Thorsager M, Fischer AHL, Simakov O, Steinmetz PRH, et al. Development of the annelid axochord: insights into notochord evolution. Science. 2014:345(6202):1365-8.

101. Tomer R, Denes AS, Tessmar-Raible K, Arendt D. Profiling by image registration reveals common origin of annelid mushroom bodies and vertebrate pallium. Cell. 2010;142(5):800-9.

102. Vergara HM, Pape C, Meechan K, Zinchenko V, Genoud C, Wanner $A A$, et al. Whole-body integration of gene expression and single-cell morphology. Cell. 2021;184:1-19.

103. Verasztó C, Jasek S, Gühmann M, Shahidi R, Ueda N, Beard JD, et al. Whole-animal connectome and cell-type complement of the threesegmented Platynereis dumerilii larva. Cold Spring Harb Lab. 2020. https://doi.org/10.1101/2020.08.21.260984v2.abstract.

104. Achim K, Pettit J-B, Saraiva LR, Gavriouchkina D, Larsson T, Arendt D, et al. High-throughput spatial mapping of single-cell RNA-seq data to tissue of origin. Nat Biotechnol. 2015;33(5):503-9.

105. Vergara HM, Bertucci PY, Hantz P, Tosches MA, Achim K, Vopalensky P, et al. Whole-organism cellular gene-expression atlas reveals conserved cell types in the ventral nerve cord of. Proc Natl Acad Sci USA. 2017;114(23):5878-85.

106. Asadulina A, Panzera A, Verasztó C, Liebig C, Jékely G. Whole-body gene expression pattern registration in Platynereis larvae. EvoDevo. 2012;3(1):27.

107. Randel N, Shahidi R, Verasztó C, Bezares-Calderón LA, Schmidt S, Jékely G. Inter-individual stereotypy of the Platynereis larval visual connectome. Elife. 2015;4:e08069.

108. Shahidi R, Williams EA, Conzelmann M, Asadulina A, Verasztó C, Jasek $S$, et al. A serial multiplex immunogold labeling method for identifying peptidergic neurons in connectomes. Elife. 2015. https://doi.org/10. 7554/eLife.11147.

109. Häfker NS, Tessmar-Raible K. Rhythms of behavior: are the times changin'? Curr Opin Neurobiol. 2020;60:55-66.
110. Häfker NS, Meyer B, Last KS, Pond DW, Hüppe L, Teschke M. Circadian clock involvement in zooplankton diel vertical migration. Curr Biol. 2017;27(14):2194-201.

111. Arboleda E, Zurl M, Waldherr M, Tessmar-Raible K. Differential impacts of the head on Platynereis dumerilii peripheral circadian rhythms. Front Physiol. 2019;11(10):900.

112. Zurl M, Poehn B, Rieger D, Krishnan S, Rokvic D, Rajan VBV, et al. Two light sensors decode moonlight versus sunlight to adjust a plastic circadian/circalunidian clock to moon phase. bioRxiv. 2021. https://doi. org/10.1101/2021.04.16.440114v1.

113. Andreatta G, Tessmar-Raible K. The still dark side of the moon: molecular mechanisms of lunar-controlled rhythms and clocks. J Mol Biol. 2020;432(12):3525-46.

114. Schenk S, Bannister SC, Sedlazeck FJ, Anrather D, Minh BQ, Bileck A, et al. Combined transcriptome and proteome profiling reveals specific molecular brain signatures for sex, maturation and circalunar clock phase. Elife. 2019. https://doi.org/10.7554/eLife.41556.

115. Poehn B, Krishnan S, Zurl M, Coric A, Rokvic D, Arboleda E, et al. A Cryptochrome adopts distinct moon- and sunlight states and functions as moonlight interpreter in monthly oscillator entrainment. bioRxiv. 2021. https://doi.org/10.1101/2021.04.16.439809v1.

116. Rajan VBV, Sören Häfker N, Arboleda E, Poehn B, Gossenreiter T, Gerrard $E$, et al. Seasonal variation in UVA light drives hormonal and behavioural changes in a marine annelid via a ciliary opsin. Nat Ecol Evol. 2021;5(2):204-18.

117. Meyer $B$, Hüppe $L$, Payton $L$. Timing requires the right amount and type of light. Nat Ecol Evol. 2021;5(2):153-4.

118. de Rosa R, Prud'homme B, Balavoine G. Caudal and even-skipped in the annelid Platynereis dumerilii and the ancestry of posterior growth. Evol Dev. 2005;7(6):574-87.

119. Kimelman D, Martin BL. Anterior-posterior patterning in early development: three strategies: anterior-posterior patterning in early development. Wiley Interdiscip Rev Dev Biol. 2012;1(2):253-66.

120. Fritzenwanker JH, Uhlinger KR, Gerhart J, Silva E, Lowe CJ. Untangling posterior growth and segmentation by analyzing mechanisms of axis elongation in hemichordates. Proc Natl Acad Sci USA. 2019;116(17):8403-8.

121. Constantinou SJ, Duan N, Nagy LM, Chipman AD, Williams TA. Elongation during segmentation shows axial variability, low mitotic rates, and synchronized cell cycle domains in the crustacean, Thamnocephalus platyurus. EvoDevo. 2020;18(11):1.

122. Gazave E, Béhague J, Laplane L, Guillou A, Préau L, Demilly A, et al. Posterior elongation in the annelid Platynereis dumerilii involves stem cells molecularly related to primordial germ cells. Dev Biol. 2013;382(1):246-67.

123. Pfeifer K, Dorresteijn AWC, Fröbius AC. Activation of Hox genes during caudal regeneration of the polychaete annelid Platynereis dumerilii. Dev Genes Evol. 2012;222(3):165-79.

124. Rebscher N, Zelada-González F, Banisch TU, Raible F, Arendt D. Vasa unveils a common origin of germ cells and of somatic stem cells from the posterior growth zone in the polychaete Platynereis dumerilii. Dev Biol. 2007;306(2):599-611.

125. Juliano CE, Swartz SZ, Wessel GM. A conserved germline multipotency program. Development. 2010;137(24):4113-26.

126. Leclère L, Jager M, Barreau C, Chang P, Le Guyader H, Manuel M, et al. Maternally localized germ plasm mRNAs and germ cell/stem cell formation in the cnidarian Clytia. Dev Biol. 2012;364(2):236-48.

127. Alié A, Hayashi T, Sugimura I, Manuel M, Sugano W, Mano A, et al. The ancestral gene repertoire of animal stem cells. Proc Natl Acad Sci USA 2015;112(51):E7093-100.

128. Fierro-Constaín L, Schenkelaars Q, Gazave E, Haguenauer A, Rocher C, Ereskovsky A, et al. The conservation of the germline multipotency program, from sponges to vertebrates: a stepping stone to understanding the somatic and germline origins. Genome Biol Evol. 2017;9(3):474-88.

129. Özpolat BD, Bely AE. Developmental and molecular biology of annelid regeneration: a comparative review of recent studies. Curr Opin Genet Dev. 2016;40:144-53. https://doi.org/10.1016/j.gde.2016.07.010.

130. Hofmann DK. Regeneration and endocrinology in the polychaete Platynereis dumerilii. Wilhelm Roux's Arch Dev Biol. 1976;180(1):47-71.

131. Bely AE. Distribution of segment regeneration ability in the Annelida. Integr Comp Biol. 2006;46(4):508-18. 
132. Bideau L, Kerner P, Hui J, Vervoort M, Gazave E. Animal regeneration in the era of transcriptomics. Cell Mol Life Sci. 2021. https://doi.org/10. 1007/s00018-021-03760-7.

133. Planques A, Malem J, Parapar J, Vervoort M, Gazave E. Morphological, cellular and molecular characterization of posterior regeneration in the marine annelid Platynereis dumerilii. Dev Biol. 2019;445:189-210. https:// doi.org/10.1016/j.ydbio.2018.11.004.

134. Planques A, Kerner P, Ferry L, Grunau C, Gazave E, Vervoort M. DNA methylation atlas and machinery in the developing and regenerating annelid Platynereis dumerilii. BMC Biol. 2021;19(1):148.

135. Grimmel J, Dorresteijn AWC, Fröbius AC. Formation of body appendages during caudal regeneration in Platynereis dumerilii: adaptation of conserved molecular toolsets. EvoDevo. 2016;12(7):10.

136. Yun MH. Changes in regenerative capacity through lifespan. Int J Mol Sci. 2015;16(10):25392-432.

137. Harms JW. Über ein inkretorisches Cerebralorgan bei Lumbriciden, sowie. Wilhelm Roux Arch Entwickl Mech Org. 1948;143(3-4):332-46.

138. Rebscher N. Establishing the germline in spiralian embryos. Int J Dev Biol. 2014;58(6-8):403-11.

139. Zelada González YF. Germline development in Platynereis dumerilii and its connection to embryonic patterning [Internet]. 2005. http://archiv. ub.uni-heidelberg.de/volltextserver/5432/. Accessed 12 Aug 2018

140. Hauenschild C. Normalisierung der geschlechtlichen Entwicklung kopfloser Fragmente junger oㅇ von Platynereis dumerilii (Polychaeta) durch Behandlung mit konservierten Prostomien juveniler Individuen. Helgoländer Meeresun. 1974;26(1):63-81.

141. Schenk S, Hoeger U. Annelid coelomic fluid proteins. In: Hoeger U, Harris JR, editors. Vertebrate and invertebrate respiratory proteins, lipoproteins and other body fluid proteins. Cham: Springer; 2020. p. 1-34.

142. Jha AN, Hutchinson TH, Mackay JM, Elliott BM, Pascoe PL, Dixon DR. The chromosomes Of Platynereis dumerilii (Polychaeta: Nereidae). J Mar Biol Assoc UK. 1995;75(3):551-62.

143. García-Alonso J, Ayoola JAO, Crompton J, Rebscher N, Hardege JD. Development and maturation in the nereidid polychaetes Platynereis dumerilii and Nereis succinea exposed to xenoestrogens. Comp Biochem Physiol C Toxicol Pharmacol. 2011;154(3):196-203.

144. Hardege JD, Müller CT, Beckmann M, Bartels Hardege HD, Bentley MG Timing of reproduction in marine polychaetes: the role of sex pheromones. Écoscience. 1998;5(3):395-404.

145. Hardege JD. Nereidid polychaetes as model organisms for marine chemical ecology. Hydrobiologia. 1999;402:145-61.

146. Zeeck E, Harder T, Beckmann M. Uric acid: the sperm-release pheromone of the marine polychaete Platynereis dumerilii. J Chem Ecol. 1998;24(1):13-22.

147. Der HC. hormonale einfluss des Gehirns auf die sexuelle Entwicklung bei dem polychaeten Platynereis dumerilii. Gen Comp Endocrinol. 1966;6(1):26-73

148. Leitz T. Metamorphosin A and related compounds: a novel family of neuropeptides with morphogenic activity. Ann NY Acad Sci. 1998;839:105-10.

149. Zeeck E, Hardege J, Bartels-Hardege H. Sex pheromones and reproductive isolation in two nereid species, Nereis succinea and Platynereis dumerilii. Mar Ecol Prog Ser. 1990;67(2):183-8.

150. Zeeck E, Harder T, Beckmann M, Müller CT. Marine gamete-release pheromones. Nature. 1996;382(6588):214-214.

151. Röhl I, Schneider B, Schmidt B, Zeeck E. L-Ovothiol A: the egg release pheromone of the marine polychaete Platynereis dumerilii: Annelida: Polychaeta. Verlag der Zeitschrift für Naturforschung. 1999. https://doi. org/10.1515/znc-1999-1222.

152. Boilly-Marer Y, Lassalle B. Electrophysiological responses of Heteronereis stimulated with sex pheromones (Annelida polychaeta). J Exp Zool. 1978;205(1):119-24.

153. Hardege JD, Bartels-Hardege H, Müller CT, Beckmann M. Peptide pheromones in female Nereis succinea. Peptides. 2004;25(9):1517-22.

154. Torres JP, Lin Z, Watkins M, Salcedo PF, Baskin RP, Elhabian S, et al. Smallmolecule mimicry hunting strategy in the imperial cone snail, Conus imperialis. Sci Adv. 2021. https://doi.org/10.1126/sciadv.abf2704.

155. Gambi MC, Ramella L, Sella G, Protto P, Aldieri E. Variation in genome size in benthic polychaetes: systematic and ecological relationships. J Mar Biol Assoc U K. 1997;77(4):1045-57.
156. Zantke J, Bannister S, Rajan VBV, Raible F, Tessmar-Raible K. Genetic and genomic tools for the marine annelid Platynereis dumerilii. Genetics. 2014:197(1):19-31.

157. Soldi R, Ramella L, Gambi M, Sordino P, Sella G. Genome size in polychaetes: relationship with body length and life habit. In: Dauvin JC, Laubier L, Reish DJ, editors. Paris: Editions du Museum National d'Histoire Naturelle; 1994, 129-35.

158. Tarallo A, Gambi MC, D'Onofrio G. Lifestyle and DNA base composition in polychaetes. Physiol Genomics. 2016;48(12):883-8.

159. Boore JL. Complete mitochondrial genome sequence of the polychaete annelid Platynereis dumerilii. Mol Biol Evol. 2001;18(7):1413-6.

160. Kara J, Santos CSG, Macdonald AHH, Simon CA. Resolving the taxonomic identities and genetic structure of two cryptic Platynereis Kinberg species from South Africa. Invertebr Syst. 2020;34(6):618-36.

161. Conzelmann M, Williams EA, Krug K, Franz-Wachtel M, Macek B, Jékely G. The neuropeptide complement of the marine annelid Platynereis dumerilii. BMC Genomics. 2013;20(14):906.

162. Altincicek B, Vilcinskas A. Analysis of the immune-related transcriptome of a lophotrochozoan model, the marine annelid Platynereis dumerilii. Front Zool. 2007:6(4):18.

163. Simakov O, Kawashima T, Marlétaz F, Jenkins J, Koyanagi R, Mitros T, et al. Hemichordate genomes and deuterostome origins. Nature. 2015;527(7579):459-65.

164. Putnam NH, Butts T, Ferrier DEK, Furlong RF, Hellsten U, Kawashima T, et al. The amphioxus genome and the evolution of the chordate karyotype. Nature. 2008;453(7198):1064-71.

165. Chipman AD, Ferrier DEK, Brena C, Qu J, Hughes DST, Schröder R, et al. The first myriapod genome sequence reveals conservative arthropod gene content and genome organisation in the centipede Strigamia maritima. PLoS Biol. 2014;12(11):e1002005.

166. Simakov O, Marletaz F, Cho S-J, Edsinger-Gonzales E, Havlak P, Hellsten $\mathrm{U}$, et al. Insights into bilaterian evolution from three spiralian genomes. Nature. 2013:493(7433):526-31.

167. Wang S, Zhang J, Jiao W, Li J, Xun X, Sun Y, et al. Scallop genome provides insights into evolution of bilaterian karyotype and development. Nat Ecol Evol. 2017;1(5):120.

168. Raible F, Tessmar-Raible K, Osoegawa K, Wincker P, Jubin C, Balavoine G, et al. Vertebrate-type intron-rich genes in the marine annelid Platynereis dumerilii. Science. 2005;310(5752):1325-6.

169. Hui JHL, McDougall C, Monteiro AS, Holland PWH, Arendt D, Balavoine $G$, et al. Extensive chordate and annelid macrosynteny reveals ancestral homeobox gene organization. Mol Biol Evol. 2012;29(1):157-65.

170. Janssen R, Le Gouar M, Pechmann M, Poulin F, Bolognesi R, Schwager EE, et al. Conservation, loss, and redeployment of Wnt ligands in protostomes: implications for understanding the evolution of segment formation. BMC Evol Biol. 2010;1(10):374.

171. André A, Ruivo R, Capitão A, Froufe E, Páscoa I, Costa Castro LF, et al. Cloning and functional characterization of a retinoid $X$ receptor orthologue in Platynereis dumerilii: an evolutionary and toxicological perspective. Chemosphere. 2017;182:753-61.

172. Handberg-Thorsager M, Gutierrez-Mazariegos J, Arold ST, Nadendla EK, Bertucci PY, Germain P, et al. The ancestral retinoic acid receptor was a low-affinity sensor triggering neuronal differentiation. Sci Adv. 2018;4(2):eaao1261.

173. Gazave E, Lemaitre QIB, Balavoine G. The Notch pathway in the annelid Platynereis: insights into chaetogenesis and neurogenesis processes. Open Biol. 2017. https://doi.org/10.1098/rsob.160242.

174. Gazave E, Guillou A, Balavoine G. History of a prolific family: the Hes/ Hey-related genes of the annelid Platynereis. EvoDevo. 2014;5:29.

175. Christodoulou F, Raible F, Tomer R, Simakov O, Trachana K, Klaus S, et al. Ancient animal microRNAs and the evolution of tissue identity. Nature. 2010:463(7284):1084-8.

176. Simionato E, Kerner P, Dray N, Le Gouar M, Ledent V, Arendt D, et al. atonal- and achaete-scute-related genes in the annelid Platynereis dumerilii: insights into the evolution of neural basic-Helix-Loop-Helix genes. BMC Evol Biol. 2008;9(8):170

177. Kerner P, Simionato E, Le Gouar M, Vervoort M. Orthologs of key vertebrate neural genes are expressed during neurogenesis in the annelid Platynereis dumerilii. Evol Dev. 2009;11(5):513-24. 
178. Demilly A, Steinmetz P, Gazave E, Marchand L, Vervoort M. Involvement of the $\mathrm{Wnt} / \beta$-catenin pathway in neurectoderm architecture in Platynereis dumerilii. Nat Commun. 2013;4:1915.

179. Bauknecht $P$, Jékely $G$. Large-scale combinatorial deorphanization of Platynereis neuropeptide GPCRs. Cell Rep. 2015;12(4):684-93.

180. Bauknecht $P$, Jékely $G$. Ancient coexistence of norepinephrine, tyramine, and octopamine signaling in bilaterians. BMC Biol. 2017;15(1):6

181. Lidke AK, Bannister S, Löwer AM, Apel DM, Podleschny M, Kollmann $M$, et al. 17ß-Estradiol induces supernumerary primordial germ cells in embryos of the polychaete Platynereis dumerilii. Gen Comp Endocrinol. 2014;196:52-61.

182. Hui JHL, Raible F, Korchagina N, Dray N, Samain S, Magdelenat G, et al. Features of the ancestral bilaterian inferred from Platynereis dumerilii ParaHox genes. BMC Biol. 2009;23(7):43.

183. Bellan $\mathrm{G}$. Relationship of pollution to rocky substratum polychaetes on the French Mediterranean coast. Mar Pollut Bull. 1980;11(11):318-21.

184. Hutchinson TH, Jha AN, Dixon DR. The polychaete Platynereis dumerilii (Audouin and Milne-Edwards): a new species for assessing the hazardous potential of chemicals in the marine environment. Ecotoxicol Environ Saf. 1995;31(3):271-81.

185. Palau-Casellas A, Hutchinson TH. Acute toxicity of chlorinated organic chemicals to the embryos and larvae of the marine worm Platynereis dumerilii (Polychaeta: Nereidae). Environ Toxicol Water Qual. 1998;13(2):149-55.

186. Jha AN, Hutchinson TH, Mackay JM, Elliott BM, Dixons DR. Evaluation of the genotoxicity of municipal sewage effluent using the marine worm Platynereis dumerilii (Polychaeta: Nereidae). Mutat Res. 1997;391(3):179-88

187. Yang M, Zhang X. Comparative developmental toxicity of new aromatic halogenated DBPs in a chlorinated saline sewage effluent to the marine polychaete Platynereis dumerilii. Environ Sci Technol. 2013;47(19):10868-76

188. García-Alonso J, Rodriguez-Sanchez N, Misra SK, Valsami-Jones E, Croteau M-N, Luoma SN, et al. Toxicity and accumulation of silver nanoparticles during development of the marine polychaete Platynereis dumerilii. Sci Total Environ. 2014;1(476-477):688-95.

189. Beckmann M, Hardege JD, Zeeck E. Effects of the volatile fraction of crude oil on spawning behaviour of nereids (Annelida, Polychaeta). Mar Environ Res. 1995;40(3):267-76.

190. Müller CT, Priesnitz FM, Beckmann M. Pheromonal communication in Nereids and the likely intervention by petroleum derived pollutants. Integr Comp Biol. 2005:45(1):189-93.

191. Helm C, Adamo H, Hourdez S, Bleidorn C. An immunocytochemical window into the development of Platynereis massiliensis (Annelida, Nereididae). Int J Dev Biol. 2014;58(6-8):613-22.

192. Çinar ME, Dagli E, Kurt G. Check-List of Annelida from the Coasts of Turkey. 2014;38(6). https://www.researchgate.net/publication/26504 9620_Check-List_of_Annelida_from_the_Coasts_of_Turkey. Accessed 5 Apr 2021

193. Mikac B. A sea of worms: polychaete checklist of the Adriatic Sea. Zootaxa. 2015;7(3943):1-172.

194. Valvassori G, Massa-Gallucci A, Gambi MC. Reappraisal of Platynereis massiliensis (Moquin-Tandon) (Annelida, Nereididae), a neglected sibling species of Platynereis dumerilii (Audouin \& Milne Edwards). Biologia Marina. 2015:22(1):113-6.

195. Rasmussen E. Systematics and ecology of the Isefjord marine fauna (Denmark). Ophelia. 1973;11(1):1-507.

196. Calosi P, Rastrick SPS, Lombardi C, de Guzman HJ, Davidson L, Jahnke $M$, et al. Adaptation and acclimatization to ocean acidification in marine ectotherms: an in situ transplant experiment with polychaetes at a shallow CO2 vent system. Philos Trans R Soc Lond B Biol Sci. 2013:368(1627):20120444

197. Lucey NM, Lombardi C, DeMarchi L, Schulze A, Gambi MC, Calosi P. To brood or not to brood: are marine invertebrates that protect their offspring more resilient to ocean acidification? Sci Rep. 2015;9(5):12009.
198. Ricevuto E, Kroeker KJ, Ferrigno F, Micheli F, Gambi MC. Spatio-temporal variability of polychaete colonization at volcanic $\mathrm{CO} 2$ vents indicates high tolerance to ocean acidification. Mar Biol. 2014;161(12):2909-19.

199. Gambi MC, Musco L, Giangrande A, Badalamenti F, Micheli F, Kroeker KJ. Distribution and functional traits of polychaetes in a CO2 vent system: winners and losers among closely related species. Mar Ecol Prog Ser. 2016:25(550):121-34.

200. Ricevuto E, Benedetti M, Regoli F, Spicer Jl, Gambi MC. Antioxidant capacity of polychaetes occurring at a natural $\mathrm{CO} 2$ vent system: results of an in situ reciprocal transplant experiment. Mar Environ Res. 2015;112(Pt A):44-51.

201. Ricevuto E, Vizzini S, Gambi MC. Ocean acidification effects on stable isotope signatures and trophic interactions of polychaete consumers and organic matter sources at a CO2 shallow vent system. J Exp Mar Bio Ecol. 2015;468:105-17.

202. Foo SA, Byrne M, Ricevuto E, Gambi MC. The carbon dioxide vents of ischia, Italy, A natural system to assess impacts of ocean acidification on marine ecosystems: An overview of research and comparisons with other vent systems. In: Oceanography and Marine Biology. CRC Press; 2018. p. 237-310

203. Clements JC, Hunt HL. Marine animal behaviour in a high CO2 ocean. Mar Ecol Prog Ser. 2015;29(536):259-79.

204. Roggatz CC, Lorch M, Hardege JD, Benoit DM. Ocean acidification affects marine chemical communication by changing structure and function of peptide signalling molecules. Glob Chang Biol. 2016;22(12):3914-26

205. Nilsson GE, Dixson DL, Domenici P, McCormick MI, Sørensen C, Watson S-A, et al. Near-future carbon dioxide levels alter fish behaviour by interfering with neurotransmitter function. Nat Clim Chang. 2012;2(3):201-4

206. PlatyBrowser. A cellular gene expression atlas for Platynereis dumerilii. PlatyBrowser. https://github.com/mobie/mobie-viewer-fiji\#mmb-fiji

207. PlatyConnectome. A whole-body connectome for Platynereis dumerilii with synaptic resolution. Platynereis connectome. https://catmaid.jekel ylab.ex.ac.uk

208. Platynereis dumerilii. http://platynereis.com. Accessed 6 May 2021

209. Audouin JV, Milne EH. Classification des Annélides et description de celles qui habitent les côtes de la France. Part 3. Ann Sci Nat. 1833:1(29):195-269.

210. Kinberg JGH. Annulata nova. Öfversigt af Königlich Vetenskapsakademiens förhandlingar. 1865;22(2):167-79.

\section{Publisher's Note}

Springer Nature remains neutral with regard to jurisdictional claims in published maps and institutional affiliations.

Ready to submit your research? Choose BMC and benefit from

- fast, convenient online submission

- thorough peer review by experienced researchers in your field

- rapid publication on acceptance

- support for research data, including large and complex data types

- gold Open Access which fosters wider collaboration and increased citations

- maximum visibility for your research: over 100M website views per year

At BMC, research is always in progress.

Learn more biomedcentral.com/submissions 